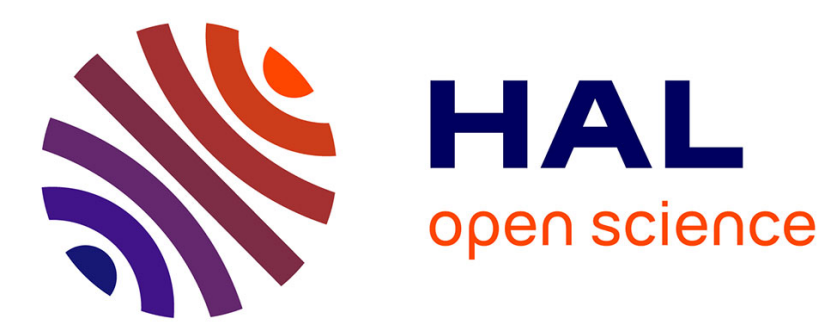

\title{
Antibacterial and Biofilm-Preventive Photocatalytic Activity and Mechanisms on P/F-Modified TiO 2 Coatings
}

Yige Yan, Charline Soraru, Valérie Keller, Nicolas Keller, Lydie Ploux

\section{- To cite this version:}

Yige Yan, Charline Soraru, Valérie Keller, Nicolas Keller, Lydie Ploux. Antibacterial and BiofilmPreventive Photocatalytic Activity and Mechanisms on P/F-Modified TiO 2 Coatings. ACS Applied Bio Materials, 2020, 3 (9), pp.5687-5698. 10.1021/acsabm.0c00467 . hal-03004434

\author{
HAL Id: hal-03004434 \\ https://hal.science/hal-03004434
}

Submitted on 2 Jan 2021

HAL is a multi-disciplinary open access archive for the deposit and dissemination of scientific research documents, whether they are published or not. The documents may come from teaching and research institutions in France or abroad, or from public or private research centers.
L'archive ouverte pluridisciplinaire HAL, est destinée au dépôt et à la diffusion de documents scientifiques de niveau recherche, publiés ou non, émanant des établissements d'enseignement et de recherche français ou étrangers, des laboratoires publics ou privés. 


\section{Antibacterial and biofilm-preventive photocatalytic}

\section{activity and mechanisms on $\mathrm{P} / \mathrm{F}$-modified $\mathrm{TiO}_{2}$}

coatings

Yige Yan ${ }^{b c}$, Charline Soraru ${ }^{c}$, Valérie Keller $^{b}$, Nicolas Keller $^{b}$, Lydie Ploux $^{a c}{ }^{*}$

a BioMaterials and BioEngineering, U1121, INSERM / Université de Strasbourg-Faculté Dentaire, 11 rue Humann, 67000 Strasbourg, France

b Institut de Chimie et Procédés pour l'Energie, l'Environnement et la Santé (ICPEES), UMR7515, CNRS / Université de Strasbourg, 25 rue Becquerel, 67087 Strasbourg Cedex, France

' Institut de Science des Matériaux de Mulhouse (IS2M), UMR7361, CNRS / Université de Haute Alsace, 15 rue Jean Starcky, 68057 Mulhouse cedex, France 


\section{KEYWORDS:}

Antibacterial $\mathrm{P} / \mathrm{F}$-modified $\mathrm{TiO}_{2}$ coating, photocatalytic activity, immediate versus long-term biofilm-preventive activity, mechanism, surface topographic properties.

\section{ABSTRACT}

Photocatalytic antibacterial and biofilm-preventive activity in liquid of heavy-metal-free coatings based on a phosphorus $(\mathrm{P})$ and fluorine $(\mathrm{F})$-modified $\mathrm{TiO}_{2}$ photocatalyst has been investigated. They reveal significantly higher immediate and longer-term (biofilm-preventive) inactivation capacity than a reference coating made of the commercial photocatalyst $\mathrm{TiO}_{2} \mathrm{P} 25$ on three bacterial species differing in cell wall type and ability to resist oxidative stress (Escherichia coli, Staphylococcus epidermidis, Pseudomonas fluorescens) (up to more than $99 \%$ reduction of colonization on $\mathrm{P} / \mathrm{F}$-modified $\mathrm{TiO}_{2}$ coating compared to about $50 \%$ on $\mathrm{P} 25 \mathrm{TiO}_{2}$ coating for 10 min UV-A illumination). This results from the P- and F-induced improvement of photocatalyst properties and from the smoother surface topography, which shortens reactive oxygen species (ROSs) diffusion to the outer membrane of the targeted adhered bacteria. Decrease in ROSsrelated impairment of cell wall, respiratory and enzymatic activities confirms the loss of ROSs throughout the bacterial cell degradation. Staphylococcus epidermidis and Pseudomonas fluorescens are less sensitive than Escherichia coli, with a probable relation to the bacterial oxygen stress defense mechanism. The coating antibacterial efficacy was highly affected by phosphate ions and the richness in dissolved oxygen of the reaction medium. 


\section{Introduction}

Surface adhesion of bacteria and formation of biofilm ${ }^{1}$ present health threat in many instances such as biomedical field, ${ }^{2}$ food industry, ${ }^{3}$ water distribution ${ }^{4}$ and wastewater treatment. ${ }^{5}$ Apart from conventional physico-chemical surface treatments, an alternative method for reducing frequency and level of surface contamination has been proposed in the last two decades: the selfdisinfecting surfaces. ${ }^{6-8}$ Nowadays, surfaces impregnated, functionalized or coated with silver or copper are the most advanced. ${ }^{9}$ However, the development of surfaces with active biocidal agent but harmless doses for human health is delicate. ${ }^{10}$ As a consequence of the surface redox properties developed by the $\mathrm{TiO}_{2}$ semiconductor under ultraviolet $\mathrm{A}$ irradiation (UVA, $320-400 \mathrm{~nm}$ ), $\mathrm{TiO}_{2}$ mostly in its anatase form exhibits strong antibacterial effect owning to the generation of various reactive oxygen species (ROSs) from photogenerated charges. ${ }^{11}$ Applying $\mathrm{TiO}_{2}$-incorporated surfaces for self-disinfection enabled bacterial inactivation, even up to complete mineralization ${ }^{12-}$ ${ }^{13}$ on a wide range of Gram-negative and Gram-positive bacteria species.

Aside from irradiation source power, ${ }^{14}$ treatment time ${ }^{15}$ and matrix (or substrate)-related factors, ${ }^{16-17}$ the intrinsic physico-chemical properties of $\mathrm{TiO}_{2}$ greatly affect the photocatalytic oxidation performance of the coating by influencing the amount, recombination rate and diffusion length of the photogenerated charges. ${ }^{18}$ The role of $\mathrm{TiO}_{2}$ itself was addressed in many studies by comparing the bactericidal performance of new $\mathrm{TiO}_{2}$ coatings ${ }^{19}$ to that made of $\mathrm{P} 25 \mathrm{TiO}_{2},{ }^{20}$ the commercial photocatalyst largely admitted as a reference. The self-disinfection properties were improved thanks to chemical modifications of $\mathrm{TiO}_{2}$, mainly involving $\mathrm{Ag}$ and $\mathrm{Cu}$. However, $\mathrm{Ag} / \mathrm{Cu}$-modified $\mathrm{TiO}_{2}$ is expected to reveal high bactericidal properties directly due to the heavy metals. ${ }^{21}$ Other studies focused on the building of $\mathrm{TiO}_{2}$-based heterojunctions ${ }^{22}$ or $\mathrm{TiO}_{2}$ doping, ${ }^{23}$ to provide self- 
disinfection properties under visible light. Meanwhile, $\mathrm{TiO}_{2}$ coatings with extended bactericidal efficiency under UVA irradiation without releasing of environmental-unfriendly agents such as heavy metals are lacking.

Efficacy of $\mathrm{TiO}_{2}$-based self-disinfection coatings also depends on the surface-related properties, especially those resulting from the weight of $\mathrm{TiO}_{2}$ deposited per surface area as well as from the surface morphology and texture, closely related to the size of the particles or of their aggregates. They directly impact the photocatalytic activity ${ }^{16}$ and also change the surface area of contact between $\mathrm{TiO}_{2}$ and the adhered bacteria, thus affecting the degree of ROSs attack on cells. Further, both chemical and topographical surface properties, which change with the photocatalyst density and chemistry, modulate the amount of adhered and hence targeted bacteria. ${ }^{24}$ If present, the matrix in which the particles are embedded also modulates the disinfection efficiency by influencing bacterial adhesion ${ }^{25-26}$ and may create a synergetic effect with the photocatalyst. ${ }^{18}$ Other factors like the presence of ions and the oxygen content in the liquid environment may also influence the photocatalytic activity, thus having dramatic consequences for the performance in real aqueous phase conditions. ${ }^{27}$ However, except regarding the matrix, these topics are usually omitted.

Besides, bacterial inactivation on $\mathrm{TiO}_{2}$-based coatings is usually addressed by counting viable or cell wall-damaged cells. ${ }^{11}$ Rare studies also investigate the photocatalytic toxicity to intracellular functions such as enzymatic and respiratory activities. ${ }^{28-29}$ However, they only touch upon $\mathrm{TiO}_{2}$ nanoparticles or nanocomposites but fail for $\mathrm{TiO}_{2}$ coatings. Hence, actual impairment of vital intracellular functions in bacteria adhered and treated thanks to $\mathrm{TiO}_{2}$ coatings has still to be clarified. Besides, bacteria are able to overcome the photocatalytic treatment thanks to ROSs defense mechanisms involving catalase and superoxide dismutase (SOD). ${ }^{30-31}$ In the case of 
oxidative damages caused by $\mathrm{TiO}_{2}$, the immediate inactivation rate of bacteria was shown to be inversely proportional to SOD and catalase activities. ${ }^{32}$ In addition, a SOD- and catalase-deficient mutant strain was reported to be much more sensitive to photocatalytic treatment than the wild strain. ${ }^{33}$ Importantly, this capacity varies with species and strains ${ }^{30}$ and can enable bacterial repair during the post-irradiation period. ${ }^{34}$ Accordingly, the high immediate antibacterial efficacy of a self-disinfection coating cannot ensure high post-photocatalytic longer-term performance. To our knowledge, this has been never investigated for immobilized $\mathrm{TiO}_{2}$ especially regarding variations according to bacterial species and their sensitivity to oxidative stress.

We report here the photocatalytic liquid-phase antibacterial activity of a novel phosphorus $(\mathrm{P})$ and fluorine $(\mathrm{F})$-modified $\mathrm{TiO}_{2}$ photocatalyst immobilized as a coating, which is expected to provide higher bactericidal efficiency under UVA light than a reference coating made of $\mathrm{TiO}_{2} \mathrm{P} 25$ catalyst without releasing any environmental-unfriendly agent. The $\mathrm{P} / \mathrm{F}$-modified $\mathrm{TiO}_{2}$ powder was developed in a previous work and revealed higher activity in the photocatalytic degradation of gaseous methylethylketone compared to $\mathrm{TiO}_{2} \mathrm{P} 25 .{ }^{35}$ Here, both immediate curative performance and the corresponding longer-term biofilm-preventive antibacterial efficacy of the $\mathrm{TiO}_{2}$ coatings were analyzed, for the first time, by in situ monitoring growth of bacteria adhered on such coatings. Impact of the photocatalytic treatment on the cell wall and on the vital respiratory and enzymatic functions was also in situ studied by following cell wall permeability as well as redox and esterase activities. Potential effect of the cell wall type and ability to resist oxidative stress of bacteria was questioned by using three bacterial species (E. coli, Staphylococcus epidermidis (S. epidermidis) and Pseudomonas fluorescens (P. fluorescens)) differing in these terms. Possible correlations between physical surface characteristics of the coating and chemical intrinsic properties of the 
$\mathrm{TiO}_{2}$ photocatalyst on one side, and the antibacterial efficacy on the other side were considered. Effects of certain ions and richness in dissolved oxygen of the reaction medium were also explored.

\section{Experimental}

\subsection{Sample preparation}

Aeroxide ${ }^{\circledR} \mathrm{P} 25 \mathrm{TiO}_{2}$ photocatalyst was purchased from Evonik ${ }^{\circledR}$ (Evonik Resource Efficiency GmbH, Hanau-Wolfgang, Germany) and is referred to as "P25".

The synthesis of the novel $\mathrm{P} / \mathrm{F}$-modified $\mathrm{TiO}_{2}$ photocatalyst was described elsewhere. ${ }^{35}$ Briefly, 5 $\mathrm{g}$ of titanium (IV) isopropoxide ( $\mathrm{Ti}\left(\mathrm{O}^{\mathrm{i}} \mathrm{Pr}\right)_{4}, 97 \%$, Aldrich) was mixed in $10 \mathrm{~g}$ of propan-2-ol (AnalaR Normapur, $>99.5 \%$, VWR Chemicals), before $6.2 \mathrm{~g}$ of $2.2 \mathrm{~mol} / \mathrm{L}$ acetic acid solution containing $21.7 \mathrm{mg}$ of sodium fluoride (NaF, ACS reagent, $\geq 99 \%$, Sigma-Aldrich) and $59 \mathrm{mg}$ of phosphoric acid $\left(\mathrm{H}_{3} \mathrm{PO}_{4}(\mathrm{PA})\right.$, analytical reagent, $\geq 85 \%$, R.P.Normapur) was further added dropwise. $\mathrm{NaF}$ and PA additives provided the fluoride anions $\left(\mathrm{F}^{-}\right)$and the phosphate anions to the synthesis medium, respectively, with a F/Ti and P/Ti molar ratio of 0.03 . A white milky precipitate was formed immediately, and the solution was kept under stirring for $1 \mathrm{~h}$ before being further sealed by parafilm and aged at room temperature for 6 days without any stirring to partially generate anatase nanoparticles by crystallization. After filtration of the powder from the rest of the solvent, the solid was dispersed in $50 \mathrm{~mL}$ distilled water under stirring for $10 \mathrm{~min}$, before being separated from liquid by centrifuge. The washing-centrifuge cycle was repeated 2 times. After drying for $2 \mathrm{~h}$ at $100^{\circ} \mathrm{C}$, the so-obtained white powder was finally calcined in air at $550^{\circ} \mathrm{C}$ for $2 \mathrm{~h}$ with a heating rate of $5^{\circ} \mathrm{C} / \mathrm{min}$ in attempt to increase crystallinity and to remove fluorine adsorbed on the sample surface. ${ }^{36}$ This sample is referred to as "PANaF". 
For the preparation of coatings, $484 \mathrm{mg}$ of both $\mathrm{TiO}_{2}$ photocatalysts were separately dispersed in $1 \mathrm{ml}$ of $96 \%$ ethanol $(0.484 \mathrm{~g} / \mathrm{ml})$ followed by $5 \mathrm{~min}$ of ultrasonication in a $100 \mathrm{~W}$ ultrasonic cleaner. Then the $\mathrm{TiO}_{2}$ suspensions were evenly deposited on borosilicate glass cover slips (ROTH Karlsruhe Deckglaser $22 \times 22 \mathrm{~mm}$ ) by drop casting with a surface density of $1 \mathrm{mg} / \mathrm{cm}^{2}$, while the substrates were continuously dried from below with a hairdryer. Drying was completed in several minutes. Both $\mathrm{TiO}_{2}$ immobilized samples are referred to as " $\mathrm{TiO}_{2}$ coatings".

\subsection{Characterization of photocatalysts}

X-ray diffraction (XRD) patterns of $\mathrm{TiO}_{2}$ powders were recorded on a D8 Advance Brucker powder diffractometer in a $\theta / \theta$ mode and using the $\mathrm{K}_{1}$ radiation of $\mathrm{Cu}$ at $1.5406 \AA$. Surface area of $\mathrm{TiO}_{2}$ powders were measured on an ASAP2010 Micromeritics Tristar 3000 analyzer using $\mathrm{N}_{2}$ as an adsorbent at $77 \mathrm{~K}$. Before $\mathrm{N}_{2}$ adsorption, samples were outgassed at $150^{\circ} \mathrm{C}$ for $12 \mathrm{~h}$. BET surface area was calculated from the $\mathrm{N}_{2}$ adsorption isotherm.

Transmission Electron Microscopy (TEM) analysis of $\mathrm{TiO}_{2}$ powders was performed using a Philips CM200 in standard mode observation, equipped with thermo-ionic $\mathrm{LaB}_{6}$ filament, operating at a $200 \mathrm{kV}$ acceleration voltage. Samples were firstly grinded and sonicated in ethanol solution, before a drop of the solution was deposited onto a copper grid covered by holey carbon membrane for observation.

Surface topographical properties of $\mathrm{TiO}_{2}$ coatings were analyzed by AFM by using a NanoScope IIIa with the following parameter settings: Tapping mode; Tip thickness of $7 \mu 1$, length of $225 \mu \mathrm{m}$, width of $38 \mu \mathrm{m}$; Resonance frequency of $190 \mathrm{KHz}$; Force constant of 13-77 N/m; Image size of 
$1 \mu \mathrm{m} \times 1 \mu \mathrm{m}$ for 5 different zones on each sample. Surface roughness was extracted from each micrograph after adequate image treatment and analysis by WSxM 9.1 (www.wsxm.es).

X-ray Photoelectron Spectroscopy (XPS) surface characterization was performed on an XPS spectrometer SES-2002 (VG SCIENTA) apparatus equipped with an Al Ka $(1448.6 \mathrm{eV})$ source with a pass energy of $20 \mathrm{eV}$. The spectra were decomposed assuming contributions with DoniacSunjic shape ${ }^{37}$ and Shirley background subtraction. ${ }^{38}$

\subsection{Bacteria strains and culture methods}

$-80^{\circ} \mathrm{C}$ frozen bacterial cells were spread on LB (Lysogeny broth, Sigma-Aldrich) agar plate and cultured for two nights at $30^{\circ} \mathrm{C}$ for E. coli $\mathrm{SCC} 1,{ }^{39}$ or $37^{\circ} \mathrm{C}$ for S. epidermidis ATCC 35983 (CIP 106510), or on BHI (Brain-Heart-Infusion, Sigma-Aldrich) agar plate at $30^{\circ} \mathrm{C}$ for $P$. fluorescens ATCC 13525 (CIP 69.13T). Then, precultures were prepared with one colony of E. coli or $S$. epidermidis in LB, or of $P$. fluorescens in $\mathrm{BHI}$, before overnight incubation at $30^{\circ} \mathrm{C}, 37^{\circ} \mathrm{C}$ and $30^{\circ} \mathrm{C}$, respectively. Cultures were prepared with $10 \%$ volume of the precultures in fresh LB for $E$. coli and S. epidermidis, and with 33.3\% volume of the preculture in fresh BHI for P. fluorescens. Cultures were then incubated for $4 \mathrm{~h}$ at $30^{\circ} \mathrm{C}$ or $37^{\circ} \mathrm{C}$ before bacteria were harvested by centrifugation. Harvested bacteria pellets were re-suspended either in physiological $\mathrm{NaCl}(9 \mathrm{~g} / \mathrm{L}$, pH 6.8) solution or in the so-called M63G, a E. coli-selective minimum medium (pH 6.8). ${ }^{40}$ The obtained bacterial suspensions were adjusted to an absorbance at $600 \mathrm{~nm}\left(\mathrm{~A}_{600} \mathrm{~nm}\right)$ of $0.1\left(5 \times 10^{7}\right.$ $\mathrm{CFU} \mathrm{mL} L^{-1}$ ) for being ready to inoculate the $\mathrm{TiO}_{2}$ coatings. As a reference, i.e. internal control of bacterial adhesion and sessile population growth, cleaned borosilicate glass cover slip surface was inoculated and further analyzed similarly to the $\mathrm{TiO}_{2}$ coatings. 


\subsection{Photocatalytic antibacterial activity of $\mathrm{TiO}_{2}$ coatings}

\subsubsection{Immediate antibacterial effect}

Coatings were sterilized by UVC irradiation $(\lambda=245 \mathrm{~nm})$ for $7 \mathrm{~min}$ at a $2 \mathrm{~cm}$ distance before immersion in $3 \mathrm{ml}$ of freshly-prepared M63G medium (exclusively for E. coli) or physiological $\mathrm{NaCl}(9 \mathrm{~g} / \mathrm{L})$ medium (for all three species) in Petri dishes (ROTH, standard petri dish, PS, $35 \mathrm{~mm}$ diameter, $10 \mathrm{~mm}$ height). After $3 \mathrm{~h}$ of incubation at $30^{\circ} \mathrm{C}$ or $37^{\circ} \mathrm{C}$, the coatings were washed three times by $2 \mathrm{ml}$ physiological $\mathrm{NaCl}$ without creating air-surface interface and ended being immersed in the last washing solution. Two of the three identical coatings of each type were exposed for 10 min or $45 \mathrm{~min}$ (and $3 \mathrm{~h}$ if necessary i.e. only for P. fluorescens) to UVA irradiation. The third coating was maintained without irradiation as a non-illuminated reference. The UVA irradiation was provided by using a 8W UV-A blacklight lamp (Sylvania Blacklight Blue F8W/BLB T5) located at a $1.5 \mathrm{~cm}$ distance above the coating samples (light distribution centered on $\lambda=365 \mathrm{~nm}$ with a received irradiance of $30 \mathrm{~W} / \mathrm{m}^{2}$ recorded using a RPS900-W ILT wideband spectroradiometer). For each illumination duration on control, P25 and PANaF coatings, experiments were repeated three times using three identical coating duplicates of each coating type. A last washing was performed after photocatalytic treatment to remove any planktonic bacteria. And in this last washing solution, Fluorescent Syto9® (Aldrich-Sigma) and propidium iodide (PI, Aldrich-Sigma) dyes were added (no Syto9® stain for E. coli SCC1) to stain viable or membrane-damaged bacteria respectively.

Observations of coating's colonization by bacteria were then conducted under confocal microscope (LSM700, Carl ZEISS) equipped with a X63 water immersion objective (W Plan 
Apochromat X63/1.0, $2.0 \mathrm{~mm}$ ) and working in fluorescence mode with the excitation laser at 488 $\mathrm{nm}$ and with acquisition wavelength at $528 \mathrm{~nm}$ and $645 \mathrm{~nm}$ for Syto9® (GFP for E. coli SCC1) and PI emission, respectively. Bacteria with active green GFP metabolism (for E. coli) or stained in green by Syto9® (for S. epidermidis and P.fluorescens) are called "Live" in the following text, while those with damaged membrane as demonstrated by the red staining of PI (for all bacteria species), are called "Damaged" in the following text. The obtained double-channel images in RGB form were analyzed via Image J $1.47 \mathrm{~V} ®$ software to access quantity of stained bacteria in terms of surface coverage fraction. Three different locations of each surface sample were observed, located on the diagonal line (Figure S1).

\subsubsection{Longer-term biofilm-preventive antibacterial effect}

The longer-term antibacterial efficiencies of the coatings, i.e. post photocatalytic action, were determined for different UVA illumination durations. The general procedure is similar to that conducted for immediate antibacterial effect analysis, except that the coatings were put back into an adequate nutritive culture medium immediately after UVA illumination. They were kept overnight at $30^{\circ} \mathrm{C}$ or $37^{\circ} \mathrm{C}$ for E. coli or P. fluorescens, and S. epidermidis respectively, before being washed and stained for the final confocal microscopy observation. For the $P$. fluorescens strain, a 3 h UVA illumination experiment was also performed.

\subsubsection{Photocatalytic action mechanism}

The experimental procedure was similar to that used for the analysis of immediate antibacterial photocatalytic effect but conducted on E. coli PHL 628, a biofilm-making K12 MG1655 derivate strain ${ }^{41}$ without fluorescence properties like that of $E$. coli SCC1. After UVA illumination, Calcein AM (CAM, Aldrich-Sigma) and 5-cyano-2,3-ditolyl tetrazolium chloride (CTC, Aldrich-Sigma) fluorescent dyes were simultaneously used to stain bacteria with intact endogenous intracellular 
esterase activities and redox respiratory activities respectively. Staining was performed in LB medium to reach a detectable level of bacterial respiratory activity. ${ }^{42}$ On each surface sample, $\mathrm{NaCl} 9 \mathrm{~g} / \mathrm{L}$ solution was thus replaced by $2 \mathrm{ml}$ of solutions of CAM ( $3 \mathrm{mmol} / \mathrm{L})$ and CTC (1 $\mathrm{mmol} / \mathrm{L}$ ) dyes in LB before 20 min incubation. Surface samples were then washed once by physiological $\mathrm{NaCl} 9 \mathrm{~g} / \mathrm{L}$ medium without creating air-surface interface and finally observed under confocal microscope as described above. Excitation laser was at $488 \mathrm{~nm}$ and the emission was observed at $520 \mathrm{~nm}$ for CAM and $630 \mathrm{~nm}$ for CTC.

\subsubsection{Photocatalytic bactericidal action in oxygen-deficient condition}

Immediate antibacterial effect of photocatalysis in oxygen-deficient condition has been evaluated on the E. coli $\mathrm{SCC} 1$ strain cultured in a confined environment (Figure S2). Briefly, $20 \mu 1$ of bacterial suspension prepared with freshly-autoclaved medium (therefore with oxygen deficiency) was dropped on each coating, which was immediately covered by a glass cover slip. The air-liquid exchange interface area was thus limited at the outer edge of the double glass cover layer. Then UVA illumination was performed as described above and prolonged up to $3 \mathrm{~h}$ since the photocatalytic activity was expected to drastically decrease in confined environment. In addition to the confocal microscopy analysis performed as described above, quantity of sessile bacteria was also assessed by using a classical plate counting method. ${ }^{43}$ Glass cover slip was confirmed not to absorb neither UVA nor the fluorescence emitted by bacteria or bacterial staining.

Besides, the variation of the oxygen content during the photocatalysis action in confined environment was monitored by using an oxygen sensor patch (HIOXY Oxygen Sensor patch, IDIL). In the above described confined environment setup, the patch was stuck on the interior side of the top cover slip, sandwiching liquid along with the $\mathrm{TiO}_{2}$ coating (Figure S3). The liquid used in this experiment was either distilled water, fresh bacteria-free physiological $\mathrm{NaCl} 9 \mathrm{~g} / \mathrm{L}$ medium 
or bacteria suspension adjusted to an absorbance $\mathrm{A}_{600} \mathrm{~nm}$ of 0.1 or 1.0. Oxygen dissolved in liquid quenches the fluorescence of the sensor, allowing a modulation of the fluorescence intensity level vs. the dissolved oxygen concentration by observation under an up-right epifluorescence microscope (Olympus BX51). Excitation laser was at $405 \mathrm{~nm}$ and emission was observed at 630 $\mathrm{nm}$. UVA illumination was applied on the bottom side of the coatings with the same irradiance as before. To compare the oxygen content with and without UVA illumination, micrographs were taken with both non-illuminated and illuminated coatings.

\subsubsection{Data statistics}

Significance of the two-by-two differences between averages of bacteria's quantity on the diverse coatings was evaluated by bilateral Student's $t$ tests with significance thresholds of 0.05 . According to Scherrer, ${ }^{44}$ the alternative hypothesis $\left(\mathrm{H}_{1}: \mu_{\mathrm{P} 25} \neq \mu_{\mathrm{PANaF}}\right)$ was assumed to be true when the main hypothesis $\left(\mathrm{H}_{0}: \mu_{\mathrm{P} 25}=\mu_{\mathrm{PANaF}}\right)$ was rejected.

\section{Results and discussion}

\subsection{Immediate photocatalytic antibacterial effect on $E$. coli SCC1}

Surface fraction covered by E. coli SCC1 before and after illumination on the reference surface, P/F-modified and $\mathrm{P} 25 \mathrm{TiO}_{2}$ coatings are shown in Figure 1 and Figure S4. Colonization was similar before illumination on all the three types of surface $\left(\mathrm{TiO}_{2}\right.$ coatings and reference), which indicates that the $\mathrm{TiO}_{2}$ coatings do not present any noticeable attractive or repellent properties for bacteria compared to the reference. After surface inoculation and subsequent bacterial adhesion, no significant bacterial growth was observed neither on the reference surface nor on the $\mathrm{TiO}_{2}$ coatings, as expected in $\mathrm{NaCl} 9 \mathrm{~g} / \mathrm{L}$ medium. Regarding immediate photocatalytic effect, a $10 \mathrm{~min}$ 
UVA treatment resulted in a strong reduction of bacterial activity on $\mathrm{P} / \mathrm{F}$-modified $\mathrm{TiO}_{2}$ ("PANaF") coating, with almost complete elimination of the sessile "Live" population. In contrast, a 10 min UVA treatment on P25 coating only provided about $50 \%$ of "Live" population decrease, with high variability of the results with samples and locations on samples. This is illustrated by the confocal micrographs in Figure S5 B, C, which display very different ratios of "Live" to "Damaged" bacteria numbers depending on the analyzed region on P25 coatings. After 45 min of UVA illumination however, a similar strong reduction of the quantity of "Live" bacteria was observed on PANaF and P25 coatings. Besides, the quantity of "Damaged" bacteria increased with the irradiation time up to the colonization level by "Live" bacteria measured before illumination. The average "Damaged" gain-to-"Live" loss ratios for $10 \mathrm{~min}$ and $45 \mathrm{~min}$ illumination are 1.71 and 0.84 on P25 coatings, and 1.09 and 1.15 on PANaF coating respectively. In general, good correlation was found between loss in "Live" bacteria and gain in "Damaged" bacteria for all the coatings and all illumination time. This clearly indicates that bacteria were not eradicated; rather their cell wall was more or less strongly degraded according to coating type and illumination time.

Immediately after 10 min of UVA illumination, enzymatic and respiratory activities of bacteria on $\mathrm{TiO}_{2}$ coatings were not affected (Figure 2, Figure S6, Figure S7 and Figure S8), as shown by the absence of any significant difference in the quantities of CAM- or CTC-positive bacteria respectively. In contrast, 45 min illumination resulted in a strong reduction in the quantity of CTCpositive bacteria on both coating types, which was more significant on the PANaF coating. Reduction in respiratory activity is in accordance with the increase in physical damage of the cell wall, as shown by PI staining. A 45 min photocatalytic treatment also resulted in a loss in the quantity of CAM-positive bacteria, which was also more marked on PANaF coating than on P25 coating. This is indicative that bacteria have been hit at a sufficient level to inhibit any enzymatic 
activity in a large part of the bacterial population $(80 \%$ and $60 \%$ on PANaF and P25 coatings, respectively), even though cells were not completely degraded.

\subsection{Relation between the physico-chemical properties of the coating and the antibacterial activity on $E$. coli SCC1}

$\mathrm{PANaF} \mathrm{TiO}_{2}$ coatings present higher photocatalytic activity than the $\mathrm{P} 25$ reference coating in terms of immediate cell wall damage and reduction in vital metabolic activities of E. coli cell. Experiments conducted without illumination or without $\mathrm{TiO}_{2}$ coatings demonstrated that neither UVA illumination nor $\mathrm{TiO}_{2}$ coatings were able by them-selves to induce these antibacterial effects. Absence of toxicity of $\mathrm{TiO}_{2}$ coatings was made sure by the preservation of very high "Live" and very low "Damaged" bacteria's quantity on $\mathrm{TiO}_{2}$ coating samples in the absence of illumination (Figure S4, Figure S9). In addition, neither $10 \mathrm{~min}$ (data not shown) nor $45 \mathrm{~min}$ of UVA illumination (Figure S9) resulted in any loss of "Live" bacteria and any gain of "Damaged" ones on reference surfaces. The applied irradiance was thus unable to induce any detectable damage of bacterial cells. $3 \mathrm{~h}$ of UVA illumination had to be reached to achieve a slight killing effect on $E$. coli SCC1, with non-significant variation of the "Live" bacteria population but high increase in the "Damaged" population (Figure S10). In addition, the electrostatic interactions between the charged bacterial outer surface (negative for all known bacterial species at physiological $\mathrm{pH}$, about 7) and the material surface, which are known to impact bacterial adhesion, ${ }^{1}$ are expected to have been similar on $\mathrm{TiO}_{2} \mathrm{P} 25$ and PANaF materials. ${ }^{45}$ Both materials exhibit isoelectric point (IEP) of $5.6 \pm 0.5$ and $3.4 \pm 0.2$, respectively, ie. lower than the physiological $\mathrm{pH}$, so that both surfaces are negatively charged in the most common bacterial culture media $(\mathrm{pH}=6.8-7.0) .{ }^{46}$ This was confirmed by the experiment that showed that sessile E. coli bacteria were in similar amount on 
P25 and PANaF coatings before any photocatalytic treatment. Damage and inactivation of bacteria observed with up to $45 \mathrm{~min}$ of treatment should be thus attributed to photocatalysis, i.e. the physico-chemical properties of the $\mathrm{TiO}_{2}$ photocatalysts or of the coatings.

$\mathrm{PANaF} \mathrm{TiO}_{2}$ is expected to perform better than the $\mathrm{P} 25 \mathrm{TiO}_{2}$ reference for many different aspects. XRD patterns revealed that the $\mathrm{PANaF} \mathrm{TiO}_{2}$ powders had a smaller mean crystallite size than the $\mathrm{P} 25 \mathrm{TiO}_{2}$ reference (about 10-11 nm vs. $22 \mathrm{~nm}$ for the anatase phase in P25) (Figure 3), associated to its higher specific surface area $\left(130 \mathrm{~m}^{2} / \mathrm{g}\right.$ vs. $\left.55 \mathrm{~m}^{2} / \mathrm{g}\right)$. The results were confirmed by TEM analysis, for PANaF and $\mathrm{P} 25 \mathrm{TiO}_{2}$ powders (with a $12-15 \mathrm{~nm}$ mean crystallite size vs. $22-25 \mathrm{~nm}$, respectively). It was shown that this fine-tuned material morphology directly results from the use of phosphoric acid (PA) and sodium fluoride (NaF) additives in a P/F-assisted sol-gel synthesis of $\mathrm{TiO}_{2}$. Thanks to the use of both additives, a much higher photocatalytic activity in the gas-phase methyl ethyl ketone degradation was obtained with $\mathrm{PANaF} \mathrm{TiO}_{2}$ in comparison to $\mathrm{P} 25$. Indeed, the number of adsorption and reaction surface sites was increased and an improvement of the photogenerated electron-hole charge flow separation was proposed, which reduces the charge recombination rate. ${ }^{35}$ Here as well, the increased number of surface sites favors the production of ROS, and consequently the subsequent antibacterial effect in aqueous phase.

Besides, the surface topographic properties are likely to provide some advantage to the PANaF coating over its P25 counterpart. As measured by AFM and reported in Figure 4, strong differences in surface roughness and morphology are noticed: the surface of the P25 coating is composed of large grain-like convex structures with size of $180 \pm 35 \mathrm{~nm}$, while the PANaF coating surface is smoother (mean lateral particle size of $75 \mathrm{~nm}$ vs. $120 \mathrm{~nm}$ for PANaF and P25, respectively) and the grain size is smaller $(42 \pm 16 \mathrm{~nm})$. This is consistent with the smaller $\mathrm{TiO}_{2}$ crystal size of PANaF compared to P25. Indeed, even though the observed grains are probably aggregates rather 
than single crystals, smaller crystals are expected to form smaller aggregates than larger crystals do, if the form of primary particles is non-anisotropic. This has been especially shown for aggregates of $\mathrm{P} 25$ and of smaller size sol-gel $\mathrm{TiO}_{2} \cdot{ }^{47}$ This difference in topography does not result in different surface coverage by bacteria of the coatings as shown before UV-A illumination (Figure S4). However, the photocatalytic effect on adhered bacteria might be impacted. Due to their large size $(1-3 \mu \mathrm{m})$ compared to the $\mathrm{TiO}_{2}$ aggregates, bacterial cells lie on the coating's surface with only a limited numbers of contact points. ${ }^{48}$ On PANaF coatings, the smoother topography results in a higher number of contact points with shallower valleys in between. This is beneficial to the photocatalytic activity, ${ }^{49}$ since the reactive generated ROSs need to diffuse for a shorter distance to reach the target i.e. the bacterium at the surface of the PANaF coating compared to the P25 coating (Figure 4), which has been reported to prevent dramatic loss of the ROSs. ${ }^{50}$

\section{Longer-term, biofilm-preventive antibacterial effect}

Bacteria's fate on the coatings after treatment by photocatalysis has been investigated. Adhered $E$. coli were allowed to recover for $16 \mathrm{~h}$ in favorable growth conditions after different photocatalytic treatment times. Their amounts after the recovery period are depicted in Figure 5 and Figure S11, and some typical micrographs are shown in Figure S12. As expected, the surface coverage by "Live" bacteria without photocatalytic treatment increased from $15-20 \%$ to up to $40-50 \%$ on the $\mathrm{TiO}_{2}$ coatings after overnight culture in nutrition-rich conditions. In contrast, the surface coverage increased from nearly $0 \%$ when a prior UV-A treatment was applied for $10 \mathrm{~min}$ or $45 \mathrm{~min}$ to 15 $20 \%$ on both P25 and PANaF coatings after overnight culture. Overall, the longer-term antibacterial effect of the $\mathrm{TiO}_{2}$ coating is able to limit the bacterial overnight regrowth to roughly $60 \%$ of surface coverage relative to that on a non-treated coating (Figure $5 \mathrm{~B}$ ). This demonstrates that the few "Live" bacterial cells still adhered on the coatings after photocatalytic treatment 
(Figure 1C) were able to grow if placed in favorable conditions. However, only few bacteria that were damaged by the treatment were able to recover, as suggested by the similar fraction of bacteria remaining "Damaged" (i.e. red) after the overnight culture (10\%) (Figure 5 A) compared to the fraction measured directly after the photocatalytic treatment (10-20\%) (Figure $1 \mathrm{C}$ ).

\subsection{Variations of the photocatalytic antibacterial performance with bacterial species}

The photocatalytic antibacterial performance, regarding both immediate and longer-term effects, was expected not to depend only on the material and the coating properties, but also on the bacterial species mainly due to strong differences in resistance to oxidative stress. Investigation conducted with S. epidermidis ATCC 35983 (CIP 106510) and P. fluorescens ATCC 13525 (CIP 69.13T) strains on the PANaF and P25 coatings revealed significant differences in the photocatalytic effect compared to the results observed with E. coli.

With S. epidermidis ATCC 35983 (CIP 106510), the results reveal a strong reduction of the "Live" bacteria quantity on both the coatings after 45 min UVA illumination (Figure 6 A, Figure S13 and Figure S14 for micrograph examples). However, 10 min UVA treatment failed to cause any antibacterial effect on P25 coating and only a slight advantage of PANaF coating was evidenced with "Live" bacteria quantity being reduced to about $80 \%$ of the initial population. 10 min UVA treatment also failed to provide any antibacterial effect on P. fluorescens ATCC 13525 (CIP 69.13T) strain on the P25 coating, but also on the PANaF coating (Figure 6 B and Figure S15). Nevertheless, 45 min UVA illumination led to a significant reduction of the "Live" bacteria quantity on both P25 and PANaF coatings, but the reduction was only of about $70 \%$ on the PANaF coating and $50 \%$ on the $\mathrm{P} 25$ coating, thus not as efficient as with E. coli. In addition, as illustrated 
in confocal micrographs (Figure S16), some bacterial cells were stained as dark orange instead of red, which is the result from double cell staining by red PI and green Syto9®. This indicates that the cell wall integrity was affected, even though damages were not strong enough to allow PI to completely replace Syto9 ${ }^{\circledR}$ in DNA. Longer UVA treatment, tested for up to $3 \mathrm{~h}$ illumination, did not result in any further improvement of the antibacterial effect as seen in Figure 6 B.

After overnight growth in nutrient-rich culture medium without any previous treatment, $S$. epidermidis population that initially covered about $10 \%$ surface of the coatings grew to about $50 \%$ coverage in absence of photocatalytic treatment (comparison between Figure S15 and Figure S17). With a previous 10 min UVA treatment, the bacterial population was unchanged (49\% and 50\% on P25 and PANaF coatings respectively) (Figure 6 C, Figure S17 and Figure S18). However, with 45 min UVA illumination, longer-term growth was significantly reduced, the coverage by "Live" bacteria being lowered to $40 \%$ of the P25 coating and about $30 \%$ of the PANaF coating. "Damaged" bacteria quantity was almost unchanged after the overnight growth in favorable conditions compared to immediately after the photocatalytic treatment, which suggests that damaged bacteria were mainly unable to recover, similarly to that observed with the E. coli SCC1 strain. Thus, photocatalytic treatment of $S$. epidermidis on both $\mathrm{P} 25$ and $\mathrm{PANaF} \mathrm{TiO}_{2}$ coatings was able to inhibit the growth of a significant part of the sessile bacterial population even after a long recovery time in favorable conditions. In contrast, $45 \mathrm{~min}$ of treatment failed to avoid the formation of a thick $P$. fluorescens biofilm after post-treatment growth in nutritive medium (Figure S19) even though the micrographs suggest some moderate inhibition on both $\mathrm{TiO}_{2}$ coatings (Figure $\mathrm{S} 20$ ). A more pronounced inhibition was achieved after $3 \mathrm{~h}$ illumination as evidenced by the much less dense "Live" bacterial biomass observed in the biofilm. In addition, "damaged" bacteria were in higher quantity on the PANaF coating than on the P25 one. 
Finally, bacterial species are ranked as following in terms of their rate of inactivation after the same photocatalytic treatment on the same $\mathrm{TiO}_{2}$ coating: E. coli $>$ S. epidermidis $>$ P. fluorescens, from the most to the least sensitive. Indeed, the possible effect of differences in adhesion rate between species is rejected since the inactivation rate relates to the number of adhered bacteria of each species measured without treatment. Therefore, three species-related factors may be involved in this variation in sensitivity: 1) the production of extracellular matrix (ECM), 2) the structure properties of the bacteria cell wall and 3) the defense mechanism countering ROSs.

ECM is expected to form a screen that partially hides the $\mathrm{TiO}_{2}$ nanocrystals from the irradiation beam. ${ }^{51}$ It also probably acts as a diffusion barrier for ROSs that have been produced. ${ }^{52}$ However, illumination treatments were all carried out on bacteria just adhered ( $3 \mathrm{~h}$ of incubation) in physiologic saline solution, which is not expected to conduct to the formation of a significant biofilm. ${ }^{53}$ Hence, ECM is here expected not to have been produced in a sufficient quantity to compromise the photocatalysis effect.

Bacteria's cell wall type might also vary the bacterial susceptibility to ROSs. Indeed, both outer membrane and peptidoglycan (PGN) layers, which are the main barriers for ROSs before damaging the cytoplasmic membrane, differ with Gram-negative / Gram-positive class of bacteria (Figure 7). ${ }^{54}$ Lipopolysaccharide and lipid layers of the outer membrane of Gram-negative bacteria have been demonstrated to be easily degraded through photocatalysis. ${ }^{55-56}$ In contrast, the PGN layer, that is much thicker in Gram-positive bacteria, was shown to be the most resistant component of the cell wall. ${ }^{57}$ However, the natural pores of the PGN layer are large enough for the diffusion (bypass) of ROSs (if live long enough) in the absence of any PGN degradation. ${ }^{54}$ Therefore, variation of sensitivity based on the typical cell wall composition associated to the Gram-positive and versus Gram-negative classification is not obvious. This is in agreement with 
the literature that failed to report direct correlation between photocatalytic antibacterial efficacy and the cell wall type so far. ${ }^{58}$

Whatever the cell wall type, ROSs finally reach the cytoplasmic membrane. There, vital metabolic functions such as enzymatic and respiratory activities may be affected. ${ }^{42,59}$ This is therefore the ultimate and the most vital defensive line against many environmental stresses ${ }^{60}$. In our study, adhered E. coli cells with active enzymatic and respiratory activities were still in high number on both $\mathrm{TiO}_{2}$ coatings after 45 min of UVA treatment, although their GFP production, which signs the metabolic activity, was shown to be almost completely inactivated. Their cell wall was also almost completely damaged. In addition, the enzymatic activity was less reduced than the respiratory activity. This confirms that ROSs attacked the cytoplasmic membrane as first, which is the location of $E$. coli respiratory, while the remaining quantity of ROSs reached then the cytoplasm (Figure 7). In the bacterial cell cytoplasm, all three bacteria used in the present work had catalase and SOD, two important anti-oxidative enzymes providing defenses against ROSs. However, their capacity to inhibit ROSs varies with species. ${ }^{61}$ Facultative anaerobic $S$. epidermidis and E. coli bacteria are more sensitive to oxygen exposure than aerobic organisms that have moved towards intricate mechanisms to neutralize ROSs. ${ }^{62-64}$ Thus, Alhasawi et al. have demonstrated that an obligate aerobic wild $P$. fluorescens strain can survive in media with $500 \mu \mathrm{M}$ $\mathrm{H}_{2} \mathrm{O}_{2}$ by generating NADPH, ATP and glyoxylate in an effort to fend off ROSs. ${ }^{31}$ This pronounced difference in fighting against ROSs is the probable main cause of the difference in sensitivity to the photocatalytic treatment observed between E. coli and S. epidermidis on the one side and $P$. fluorescens on the other side. In addition, E. coli $\mathrm{K} 12$ strains such as E. coli $\mathrm{SCC} 1$ lack one of the SODs compared to environmental E. coli $\mathrm{B}$ strain. This allows us to suggest that $E$. coli $\mathrm{SCC} 1$ 
bacteria exhibit less resistance to ROSs in comparison to S. epidermidis and P. fluorescens bacteria, $P$. fluorescens being the most resistant due to adequate adaptation to aerobic conditions.

\subsection{Influence of oxygen and ions on the photocatalytic antibacterial performance}

Environmental factors such as the oxygen level and the presence of ions in the reaction medium are prone to strongly affect the photocatalytic antibacterial effects. We therefore investigated the immediate photocatalytic antibacterial effect in a confined, i.e. $\mathrm{O}_{2}$-poor, environment (Figure 8) for $E$. coli $\mathrm{SCC} 1$ strain on both $\mathrm{P} 25$ and PANaF coatings. The surface fraction covered by bacteria without treatment was low $(2 \%-5 \%)$ in agreement with the low bacteria's quantity inoculated on the surface in the confined environment (only $20 \mu \mathrm{l}$ of bacteria suspension). After a 45 min UVA treatment, neither P25 nor PANaF coating revealed any significant reduction in the quantity of "Live" bacteria, which is in a great contrast with the results obtained in the "open" aerated system used for the above reported results (Figure 1 B). The lack of significant photocatalytic activity on the confined $\mathrm{TiO}_{2}$ coatings was confirmed after $3 \mathrm{~h}$ UVA illumination (data not shown). Noticeably, the lack of antibacterial effect was associated with a color change of the $\mathrm{TiO}_{2}$ coatings (Figure S21). Typically, the coating revealed white color in aerated conditions, which was unchanged after illumination. Placed in the confined environment, the coating turned from white to a bluish color, regardless of the concentration of bacteria used for the inoculation, which is attributed to the formation of reduced $\mathrm{TiO}_{2}\left(\mathrm{Ti}^{3+}\right)$ with the formation of oxygen vacancies. ${ }^{65-66} \mathrm{By}$ using an oxygen sensor patch, an immediate and strong decrease in the level of dissolved oxygen was actually revealed by a sharp boost of fluorescence intensity upon UVA illumination in the confined condition (Figure 9). In contrast, the red fluorescence intensity was much lower upon illumination in aerated conditions, as well as in the absence of illumination in both aerated or 
confined environments, as expected for oxygen-rich media. The low level of oxygen content in the confined environment might lead to the impossibility for photogenerated electrons to be evacuated through the usual reduction of adsorbed $\mathrm{O}_{2}$ molecules. ${ }^{67}$ Hence, the photogenerated electrons accumulate in the $\mathrm{TiO}_{2}$ material, thus reducing $\mathrm{Ti}^{4+}$ species into $\mathrm{Ti}^{3+}$ centers as expected from the redox potential level of $\mathrm{Ti}^{3+}$ lower than that of anatase $\mathrm{TiO}_{2} .{ }^{66}$. The resulting $\mathrm{TiO}_{2}$ structural changes alter the photocatalytic properties. ${ }^{66}$ Besides, the lack of oxygen prevents any freeradical-induced chain scission of (bio)polymers, ${ }^{68}$ which results in the preservation of biopolymers and therefore survival of bacteria upon photocatalytic treatment. Importantly, the presence of bacteria did not enhance the color change despite the $\mathrm{O}_{2}$ uptake by bacteria for their respiratory activity, probably due to their low consumption of $\mathrm{O}_{2}$ especially in a non-nutritive medium $(\mathrm{NaCl} 9 \mathrm{~g} / \mathrm{L}) .{ }^{42}$ It should be noticed that the blue color was more intense in the liquid freshly sterilized by autoclave just before use (e.g. physiological saline water), which is attributed to the removal of the dissolved oxygen. Finally, reduction of $\mathrm{Ti}^{4+}$ into colored $\mathrm{Ti}^{3+}$ is a nonmaterial-dependent phenomenon that occurred similarly on both $\mathrm{TiO}_{2}$ coatings.

Some ions in the reaction medium were also shown to influence the photocatalytic antibacterial effect. It was especially noticed that $1 \mathrm{~h}$ of photocatalytic treatment in $\mathrm{M} 63 \mathrm{G}$ medium failed to result in any significant reduction in the "Live" bacteria's quantity on both $\mathrm{TiO}_{2}$ coatings (Figure 10), which is very different from the effect in physiological saline medium (Figure 1 B). Complementary experiment of the liquid phase photocatalytic degradation under UVA of methylene blue on the PANaF coatings in the presence or absence of M63G medium confirmed that the M63G medium inhibited the photocatalytic reaction (cf. Figure S22 and its description), even with a M63G medium diluted by 100 times with saline solution. XPS surface analysis (Table $\mathrm{S} 1$, Figure S23) revealed the characteristic doublet of $\mathrm{P} 2 \mathrm{p}_{3 / 2-1 / 2}$ orbitals for non-polymerized 
phosphate species (133.6 eV and $134.5 \mathrm{eV}$ ) in the case of the PANaF coating, as the expected consequence of using phosphoric acid as additive for the $\mathrm{TiO}_{2}$ synthesis ${ }^{35}$, while logically no phosphorous was observed in the case of P25 coating (data not shown). After immersion in M63G medium, the $\mathrm{P} / \mathrm{Ti}$ surface atomic ratio strongly increased for both $\mathrm{TiO}_{2}$ coatings (Table $\mathrm{S} 1$ ), with the appearance of an additional P 2 $\mathrm{p}_{3 / 2-1 / 2}$ orbital doublet contribution (Figure S23 A, C) similar to that observed on $\mathrm{TiO}_{2}$-based composites used to adsorb phosphate from wastewater. ${ }^{69}$ The presence of phosphate deposit was here attributed to phosphate adsorbed from the medium to the coating's surface. It was consequently the probable cause for the suppression of the photocatalytic antibacterial effect. Indeed, Rincon et al. reported that phosphate ion is the most detrimental compound among other common ions for the $\mathrm{TiO}_{2}$ photocatalytic antibacterial effect on E. coli. It acts as a poison for the photocatalyst by competing with the oxidizing radicals, by blocking the surface active sites of the photocatalyst ${ }^{27}$, and by further serving as a charge recombination center.

\section{Conclusion}

Photocatalytic antibacterial investigation was conducted under UVA irradiation on a heavymetals-free $\mathrm{P} / \mathrm{F}$-modified $\mathrm{TiO}_{2}$ coating against several bacterial species in comparison to a reference $\mathrm{TiO}_{2}-\mathrm{P} 25$ coating. In general, near-total inactivation of E. coli and S. epidermidis was obtained, with a clear of both nature and topography of the coating, and of illumination time. Significantly higher efficiency was achieved on the PANaF coating compared to its $\mathrm{TiO}_{2}-\mathrm{P} 25$ counterpart. Especially, the smaller size of the $\mathrm{PANaF} \mathrm{TiO}_{2}$ crystals lead to a smoother topography of the coating surface, which may reduce the diffusion length that the photogenerated ROSs must travel to attack the bacterial cell wall. For the first time on $\mathrm{TiO}_{2}$ coatings, in-situ investigation of 
the cell wall integrity as well as of the respiratory and intracellular esterase activities showed that the photocatalytic treatment acts on the bacterial cells by attacking the successive barriers of the cell structure, with a decreasing photocatalytic effect as ROSs progress through the cell. Besides, we have evidenced a longer-term, biofilm-preventive effect on E. coli and S. epidermidis species in good correlation with the immediate photocatalytic antibacterial effect, while complete inactivation was not achieved with $P$. fluorescens, probably due to the capacity of $P$. fluorescens to fight the ROS-induced oxygen stress. In addition, the adsorption of phosphate ions on the $\mathrm{TiO}_{2}$ surface and the lack of dissolved oxygen in the reaction medium are detrimental to the photocatalytic activity. 
A

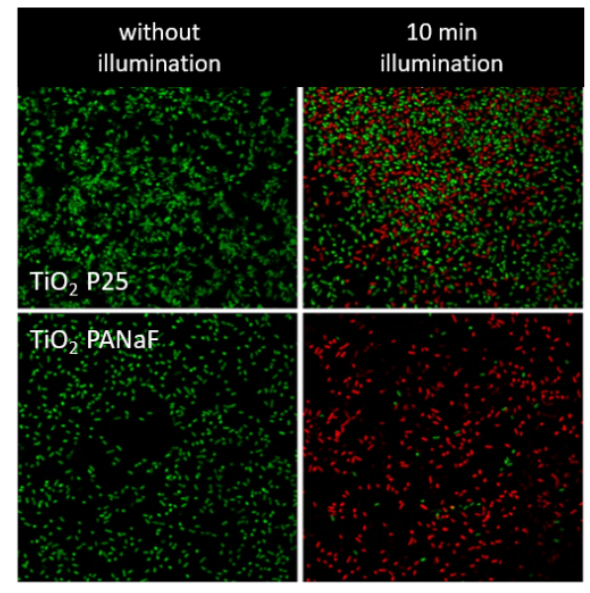

B

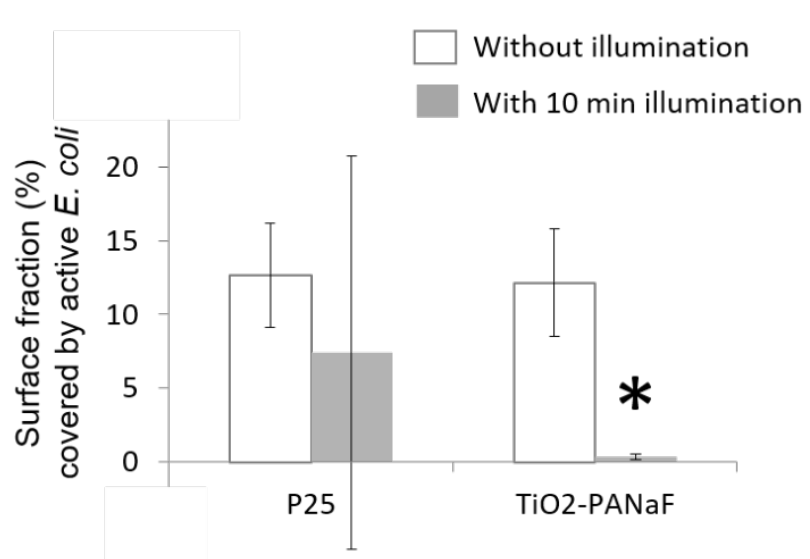

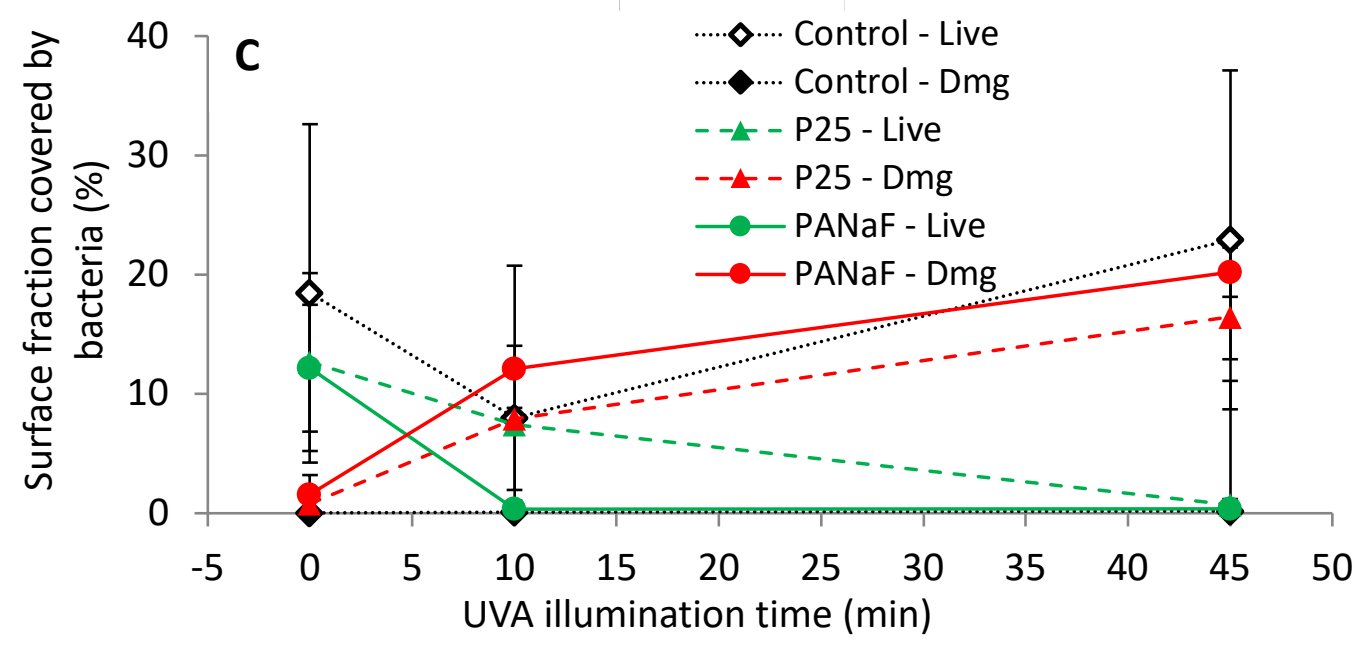

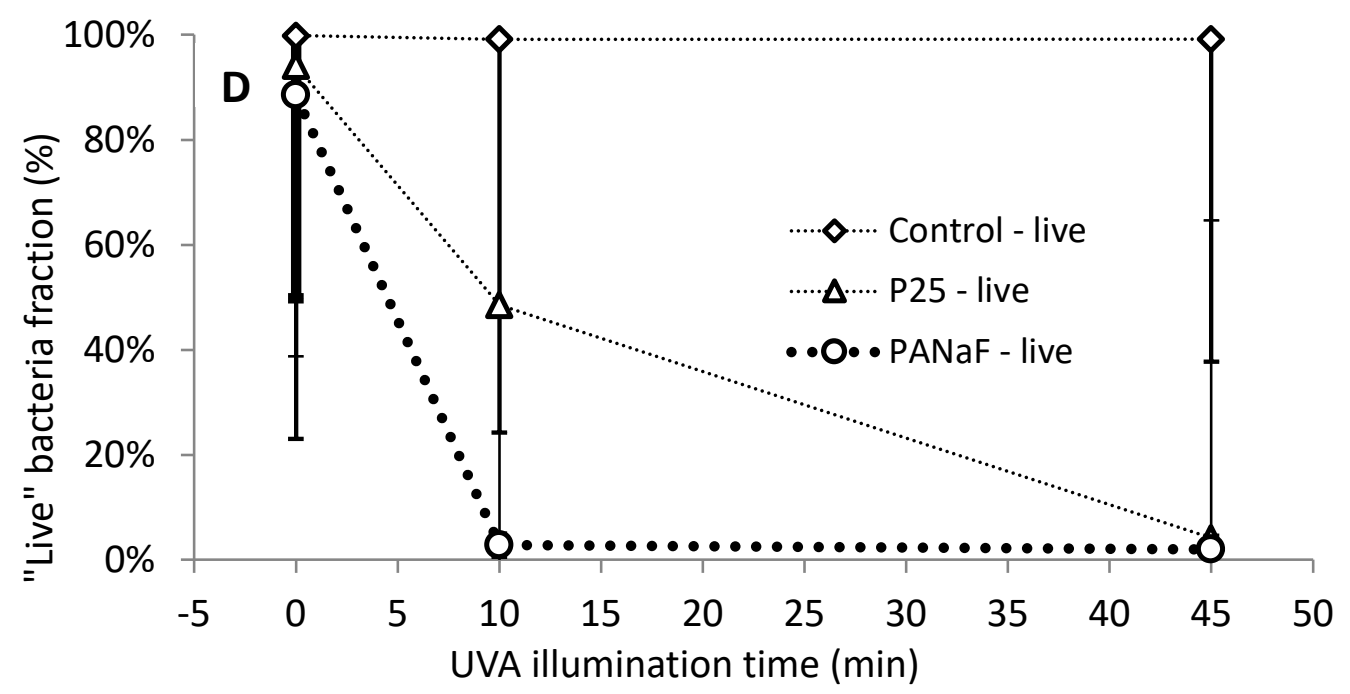

Figure 1. (A) Example of fluorescent images of E. coli SCC1 bacteria on P25 and PANaF coating 
with and without 10 min of illumination. (B) Surface fraction covered by "Live" bacteria with and without 10 min of illumination on P25 and PANaF coating. (C) Surface fraction covered by "Live" (green) and "Damaged" (marked as "Dmg") (red) bacteria and (D) fraction of "Live" bacteria in the population of $E$. coli $\mathrm{SCC} 1$ as a function of the illumination time on reference, $\mathrm{P} 25$ and PANaF coatings. Differences compared to $t=0$ are significant ( $p$-value $<0.05$ ) at all illumination length on P25 and PANaF coatings (cf. also in Figure S6). 

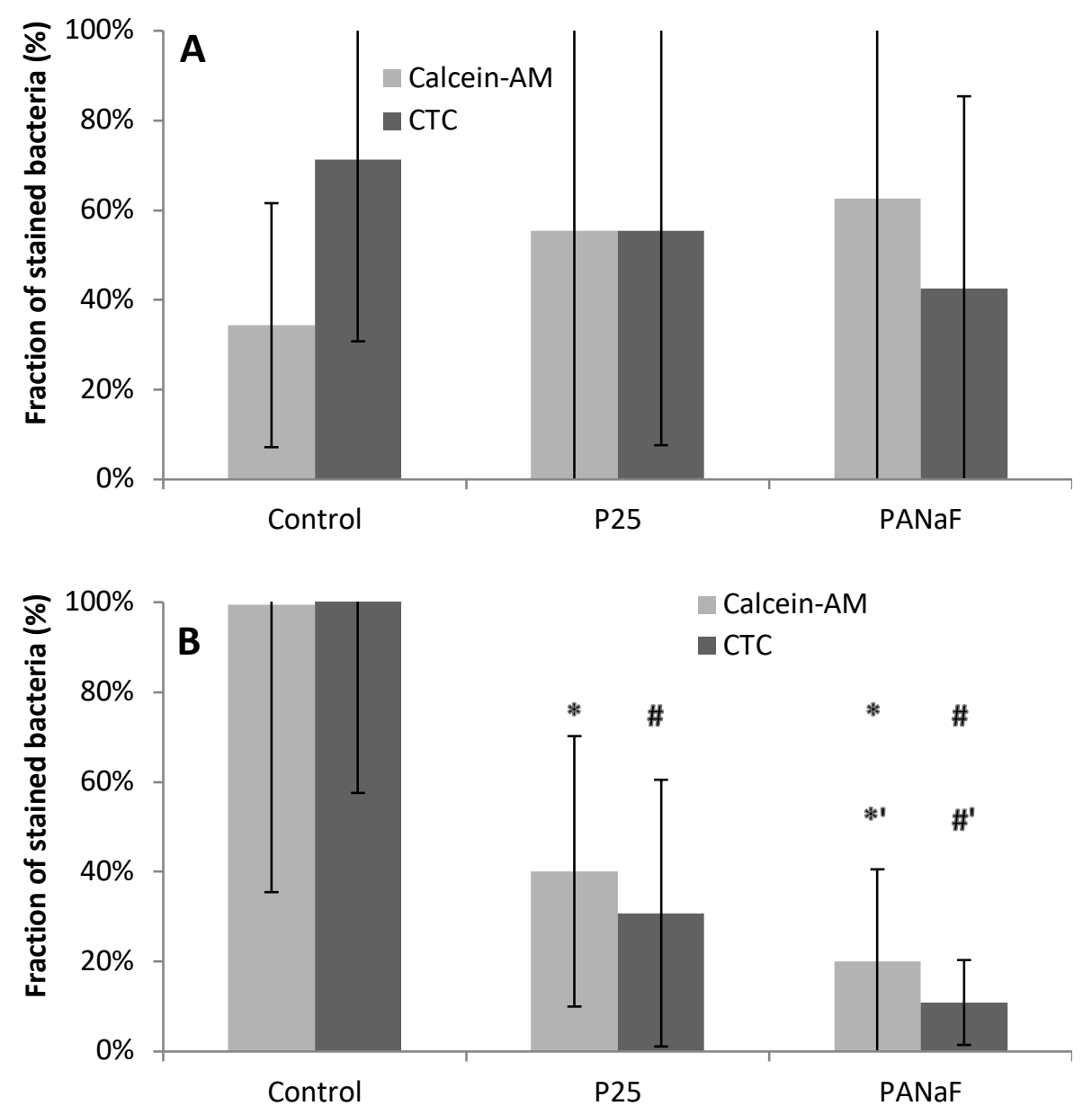

Figure 2. CAM and CTC stained E. coli PHL $628^{41}$ quantities for the reference, P25 and PANaF coatings after (A) 10 min and (B) 45 min of UVA illumination. *: Significant differences in CAM stain (p-value < 0.05) compared to "Control". \#: Significant differences in CTC stain (p-value < 0.05) compared to "Control". *': Significant differences in CAM stain ( $\mathrm{p}$-value < 0.05) compared to "P25". \#': Significant differences in CTC stain (p-value < 0.05) compared to "P25". 

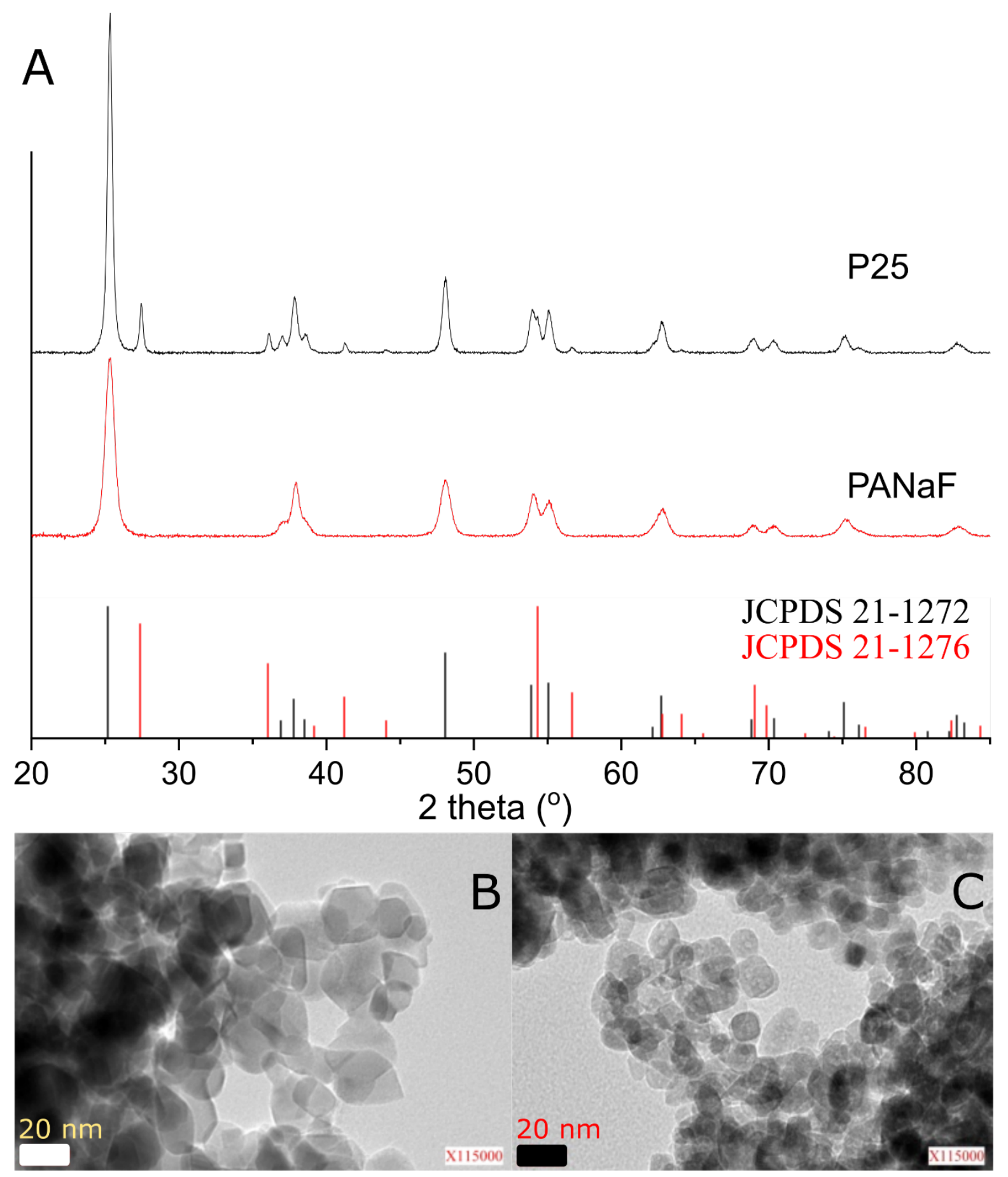

Figure 3. (A) XRD patterns of $\mathrm{TiO}_{2} \mathrm{P} 25$ and $\mathrm{TiO}_{2} \mathrm{PANaF}$. The peak positions and relative intensities for $\mathrm{TiO}_{2}$ anatase phase (black lines) and rutile phase (red lines), according to the JCPDS cards 21-1272 and 21-1276 respectively, are shown in the bottom of the frame. TEM images of (B) $\mathrm{TiO}_{2} \mathrm{P} 25$ and (C) $\mathrm{TiO}_{2}$ PANaF powder samples. 


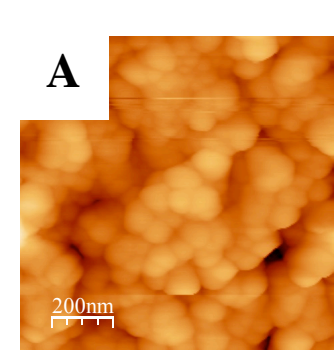

C
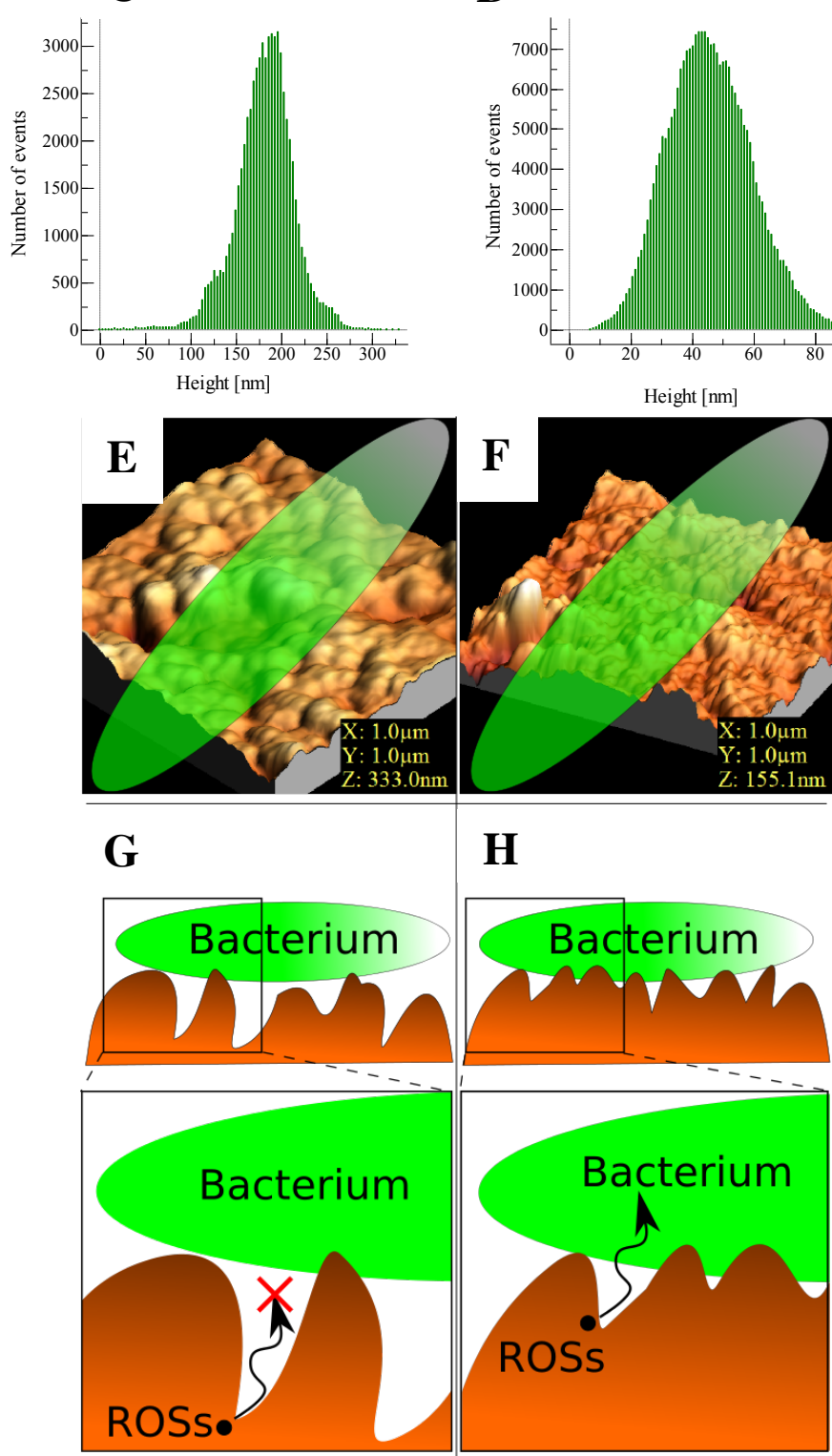

P25

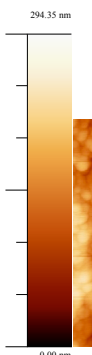

D

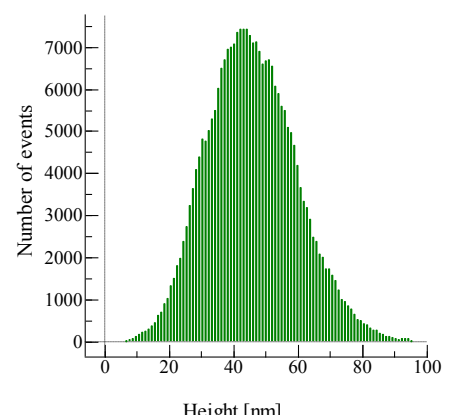

H
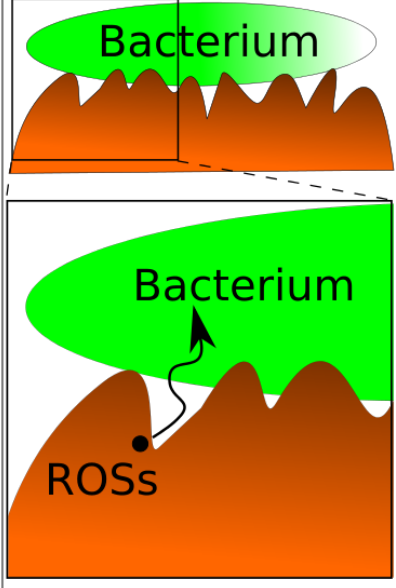

PANaF

Figure 4. (A) Topological micrographs and (C) height profiles of the $\mathrm{TiO}_{2} \mathrm{P} 25$ coating, and (B, D) similar analysis performed on the $\mathrm{TiO}_{2}$ PANaF coating surfaces, determined by AFM. 3D visualization of the surface topography of the (E) $\mathrm{P} 25$ and (F) $\mathrm{PANaF} \mathrm{TiO}_{2}$ coating, with the green 
eclipse representing a single bacterium that is shown to scale. Schematic illustration of the contact between one bacterium and both $(\mathrm{G}) \mathrm{P}^{25} \mathrm{TiO}_{2}$ and $(\mathrm{H}) \mathrm{PANaF}$ coatings, and of the diffusion pattern of ROSs depending on the $\mathrm{TiO}_{2}$ coating. 

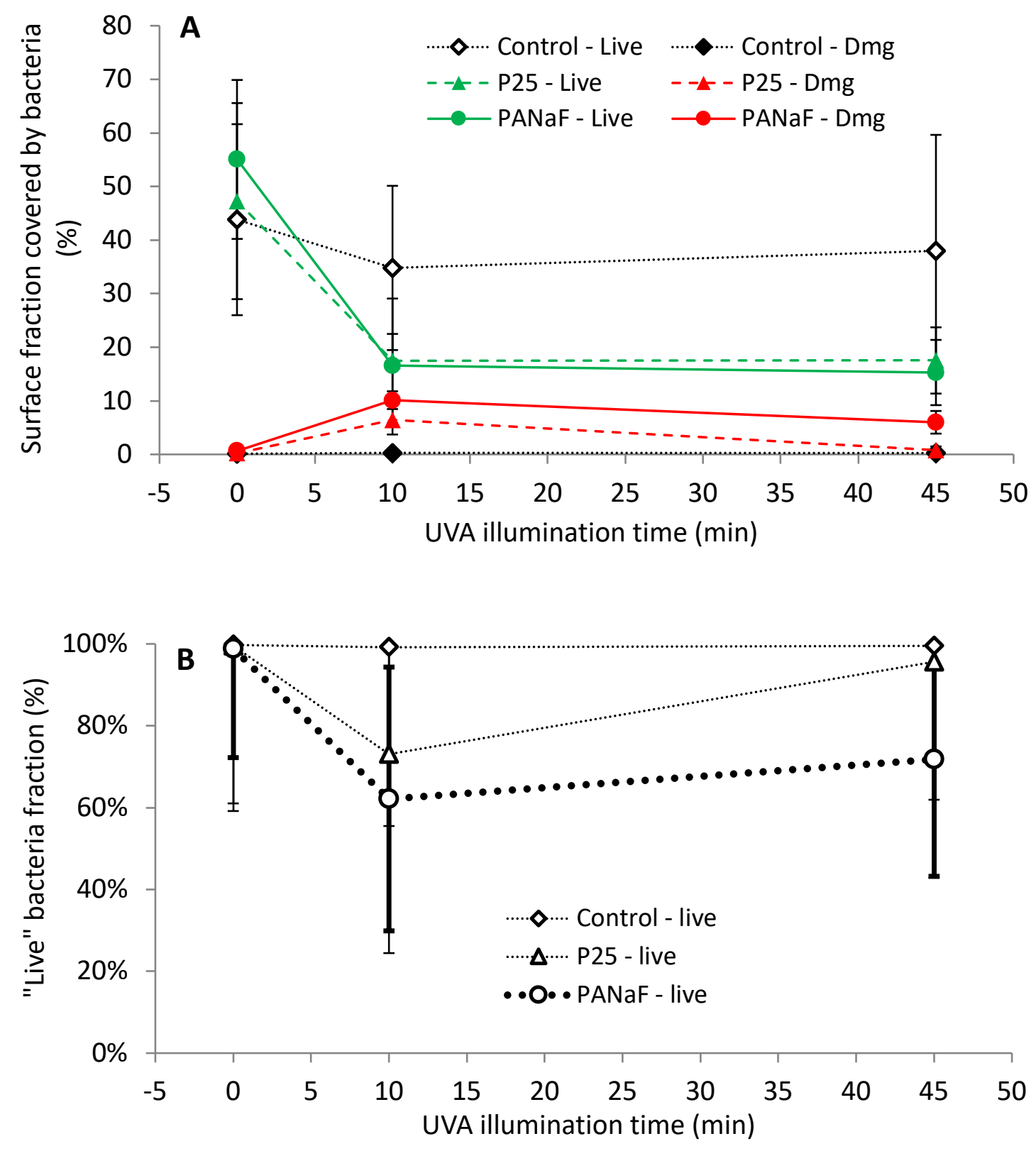

Figure 5. (A) Surface fraction covered by "Live" (green) and "Damaged (marked as Dmg)" (red) bacteria and (B) "Live" bacteria fraction of E. coli $\mathrm{SCC} 1$ after overnight growth in nutritive medium, as a function of the illumination time on control, P25 and PANaF coatings. Significant differences ( $\mathrm{p}$-value $<0.05$ ) are true compare to $\mathrm{t}=0$ at all illumination length on P25 and PANaF coatings (cf. student study in Figure S13). 

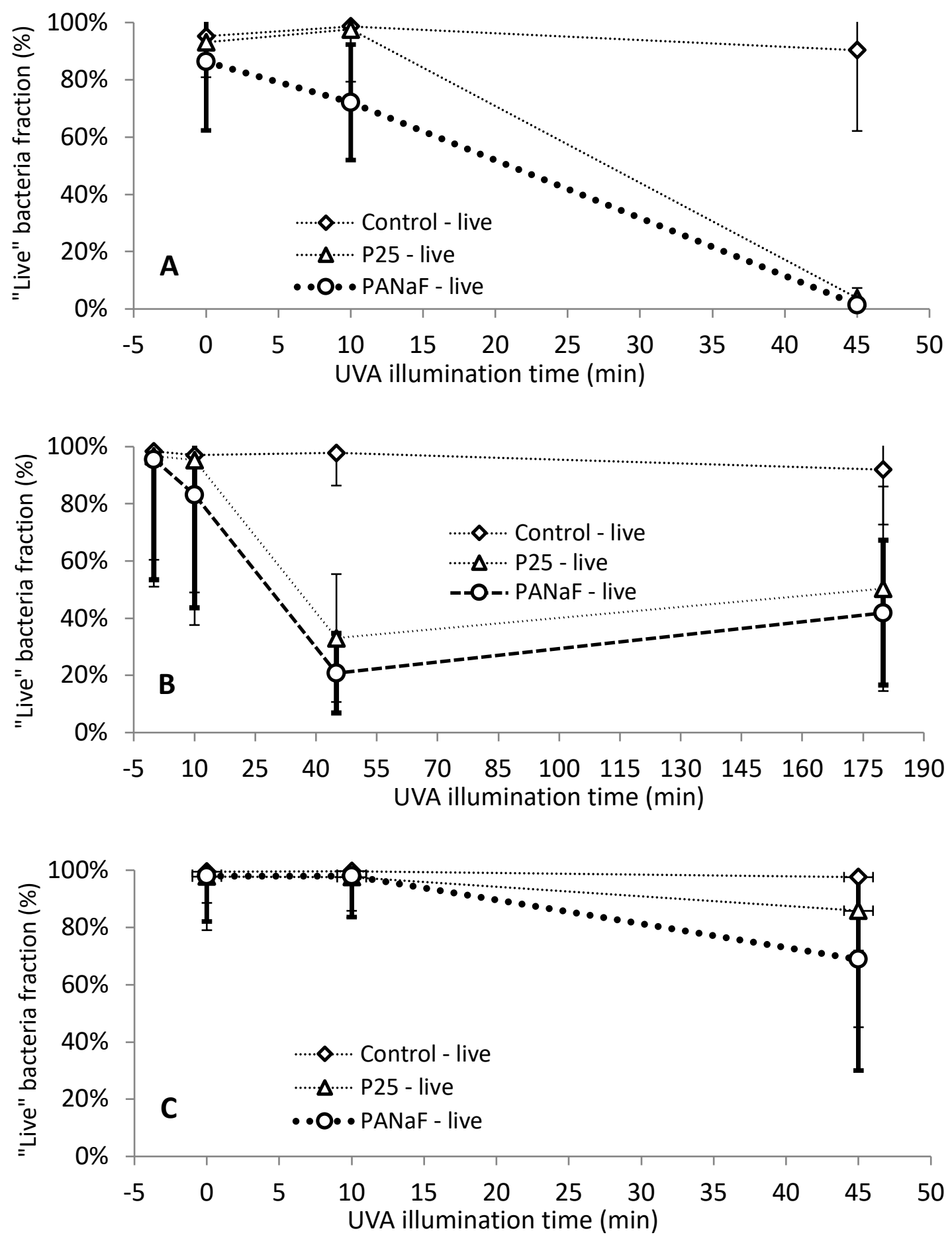


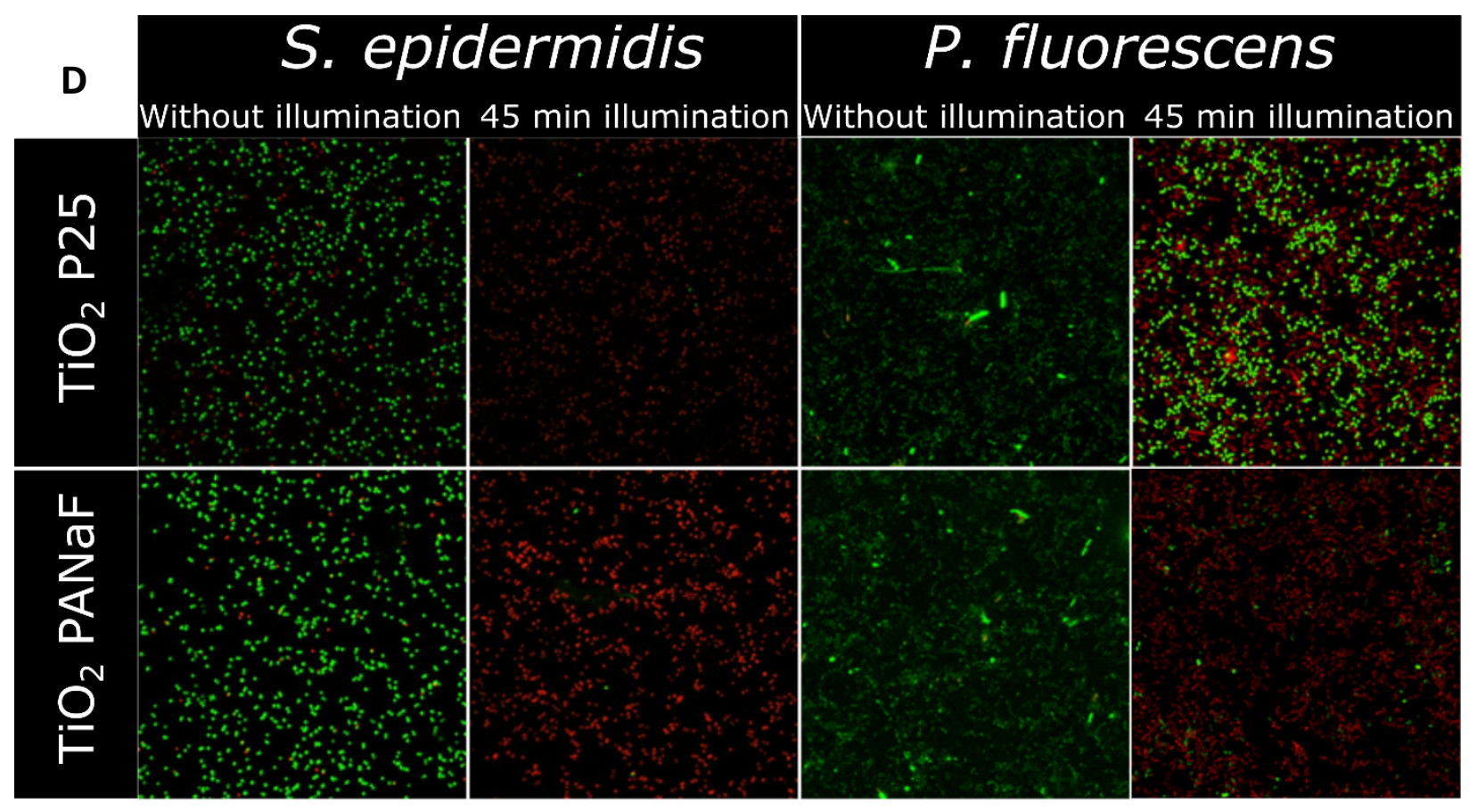

Figure 6. Fraction of "Live" bacteria after immediate photocatalytic treatment in the population of (A) S. epidermidis ATCC 35983 and (B) P. fluorescens ATCC 13525 strains as a function of the illumination time on control, P25 and PANaF coatings. Differences with $\mathrm{t}=0$ are significant ( $\mathrm{p}$ value $<0.05$ ) at all illumination length on P25 and PANaF coatings (cf. Figures S10 and S11). (C) Fraction of "Live" bacteria in the population of S. epidermidis ATCC 35983 (CIP 106510) after overnight growth in nutritive medium, as a function of the previous illumination time on control, P25 and PANaF coatings. Differences with $\mathrm{t}=0$ are significant ( $\mathrm{p}$-value $<0.05$ ) at $45 \mathrm{~min}$ illumination length on P25 and PANaF coatings (cf. Figure S15). (D) Example of fluorescent images of S. epidermidis and P. fluorescens bacteria on P25 and PANaF coating with and without 45 min of illumination. 


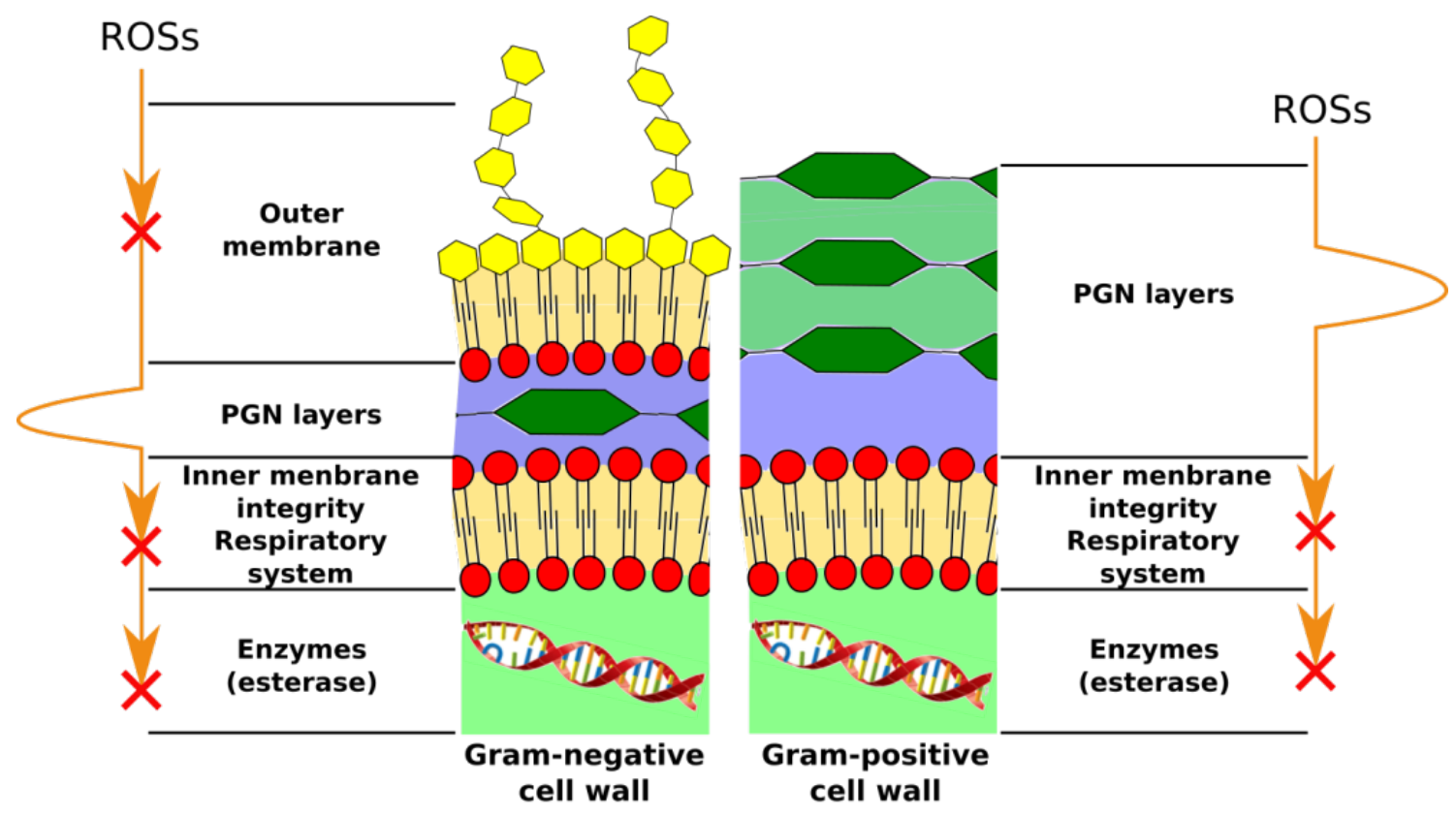

Figure 7. Illustration of the attack on the Gram-positive and Gram-negative bacteria cell wall by ROSs. The red crossovers from top to bottom represent the cell wall targets to be attacked by the photocatalytically generated ROSs. The detour around PNG layers means that ROSs do not easily degrade it but may bypass this layer thanks to pores. 


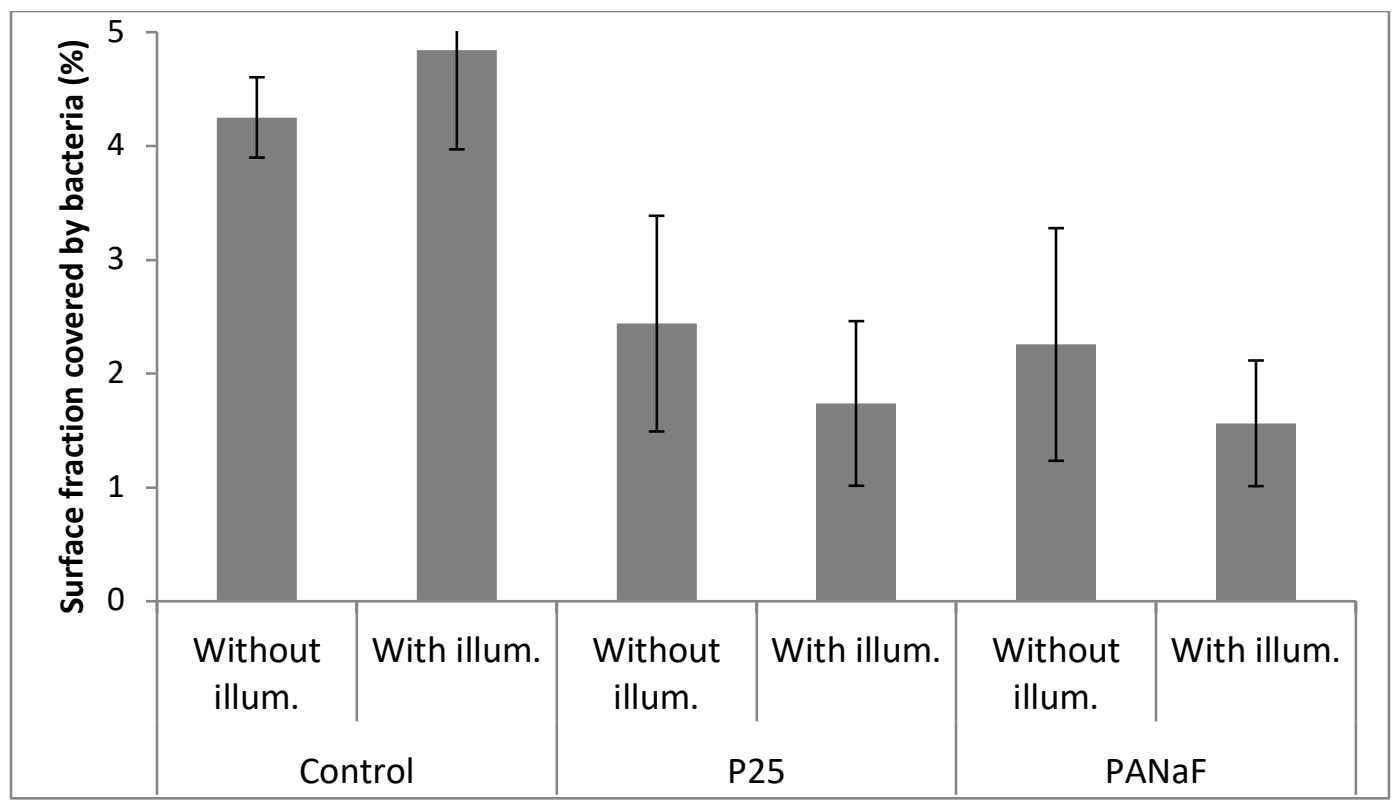

Figure 8. Immediate photocatalytic antibacterial effect on "Live" E. coli SCC1 bacteria adhered on the reference, P25 or PANaF coatings in a confined (oxygen-poor) environment, and with or without UVA illumination for 45 min. No significant differences ( $p$-value $<0.05)$ noticed between "Live" with or without 45 min of illumination on each coating. 

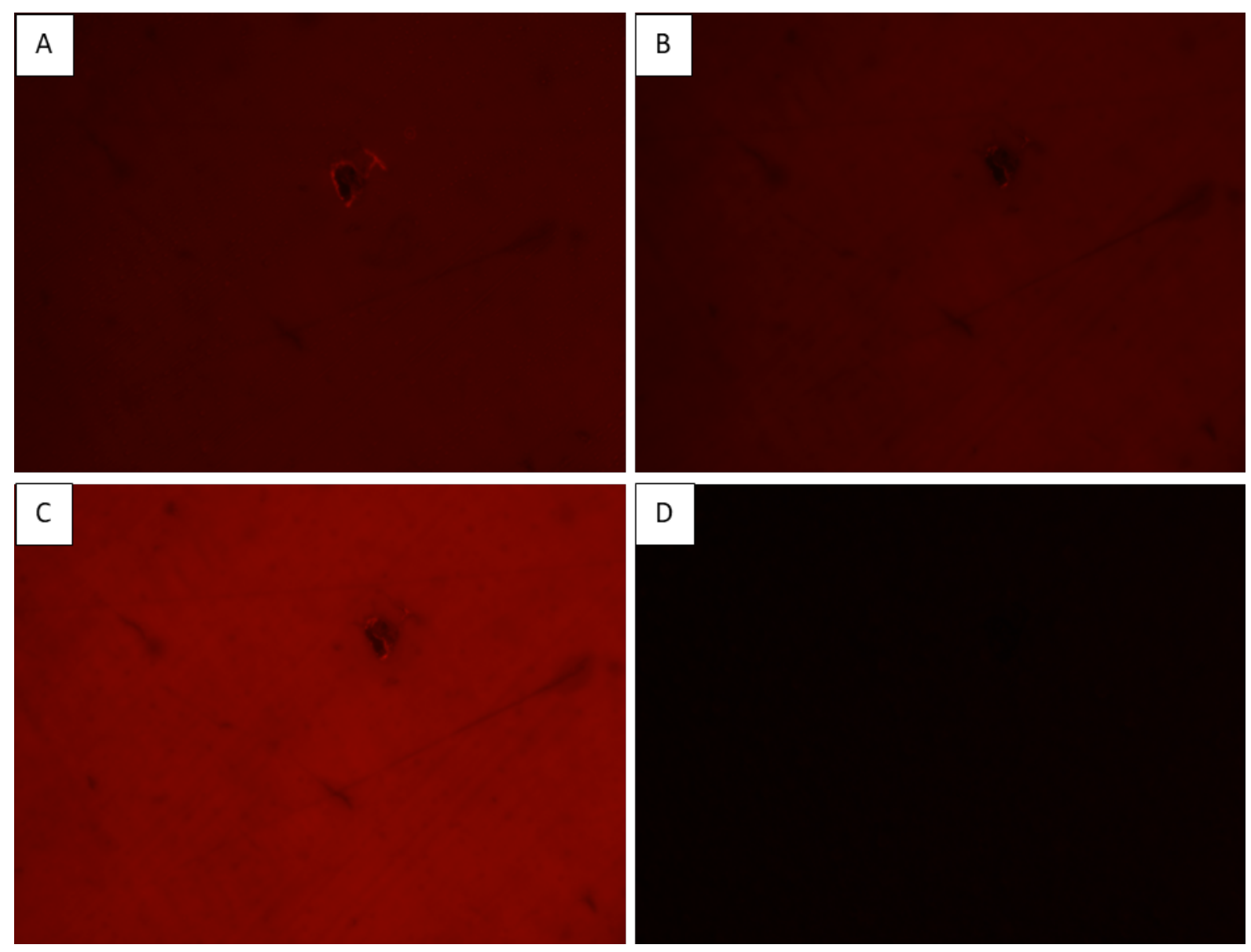

Figure 9. Fluorescent confocal images of an oxygen sensor patch in contact with a PANaF coating (A) in aerated condition, (B) in confined environment within physiological $\mathrm{NaCl} 9 \mathrm{~g} / \mathrm{L}$ medium before UVA illumination, and (C) in confined environment within physiological $\mathrm{NaCl} 9 \mathrm{~g} / \mathrm{L}$ medium during UVA illumination. (D) Fluorescence background (i.e. control condition) without any microscope laser excitation but with UVA illumination, showed uniform black color. The four photographs were taken at the same sample location. 


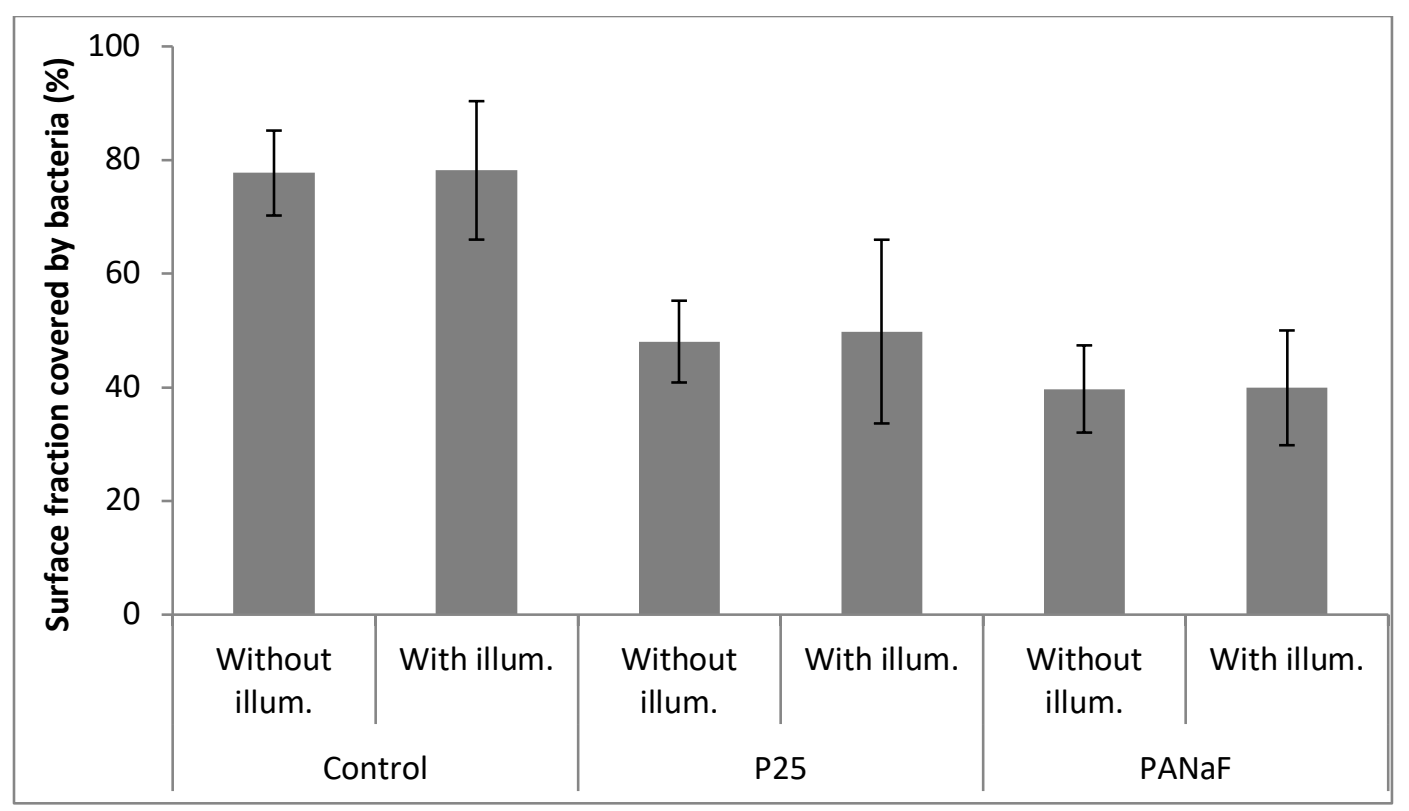

Figure 10. Immediate photocatalytic antibacterial effect on E. coli SCC1 species cultivated in M63G medium ${ }^{70}$ on P25 and PANaF coatings and with or without $1 \mathrm{~h}$ of illumination. No significant differences $(\mathrm{p}$-value $<0.05)$ are noticed for each coating with or without $1 \mathrm{~h}$ of illumination. 
Supporting Information. Examples of fluorescent images of bacteria, surface coverage by staining-positive bacteria, supplementary experimental information on studying the effect of phosphate ions adsorption and the lack of oxygen dissolved in the reaction medium on the photocatalytic bactericidal activity of $\mathrm{TiO}_{2}$ coating.

\section{Author contribution}

Yige Yan synthesized the photocatalysts and carried out most of the tests, he also co-designed certain auxiliary experiments on studying the effects of phosphate ions adsorption and the dissolved oxygen concentration on the photocatalytic bactericidal activity of $\mathrm{TiO}_{2}$ coating. Charline Soraru contributed partially to the microbiological studies.

\section{Corresponding Author}

* Corresponding author: Dr Lydie Ploux, ploux@unistra.fr, +33 (0)368855479

BioMaterials and BioEngineering, U1121

11 rue Humann 67000 Strasbourg

France

\section{Funding Sources}

This work is part of CLEANCOAT project funded by the MICA CARNOT (Materials Institute Carnot Alsace). 


\section{Acknowledgment}

Dr A. Airoudj, Dr L. Vidal and Dr S. Garreau (IS2M) are thanked for the AFM, TEM and XPS measurements respectively. We acknowledge CRT Aérial (Illkirch, France) for its assistance in complementary microbiological tests.

\section{REFERENCES}

(1) Ploux, L.; Ponche, A.; Anselme, K. Bacteria/material interfaces: role of the material and cell wall properties. Journal of Adhesion Science and Technology 2010, 24 (13-14), 2165-2201, DOI: $10.1163 / 016942410 \times 511079$.

(2) Song, R.; Zhang, Y.; Huang, Q.; Yang, Y.; Lin, L.; Liang, J.; Hu, R.; Rui, G.; Lin, C. Facile Construction of structural gradient of $\mathrm{TiO}_{2}$ nanotube arrays on medical titanium for high throughput evaluation of biocompatibility and antibacterial property. ACS Applied Bio Materials 2018, 1 (4), 1056-1065, DOI: 10.1021/acsabm.8b00288.

(3) Capita, R.; Alonso-Calleja, C. Antibiotic-resistant bacteria: a challenge for the food industry. Critical Reviews in Food Science and Nutrition 2013, 53 (1), 11-48, DOI: 10.1080/10408398.2010.519837. 
(4) Liu, S.; Gunawan, C.; Barraud, N.; Rice, S. A.; Harry, E. J.; Amal, R. Understanding, monitoring, and controlling biofilm growth in drinking water distribution systems. Environmental Science \& Technology 2016, 50 (17), 8954-8976, DOI: 10.1021/acs.est.6b00835.

(5) Rizzo, L.; Manaia, C.; Merlin, C.; Schwartz, T.; Dagot, C.; Ploy, M. C.; Michael, I.; FattaKassinos, D. Urban wastewater treatment plants as hotspots for antibiotic resistant bacteria and genes spread into the environment: A review. Science of The Total Environment 2013, 447, 345360, DOI: https://doi.org/10.1016/j.scitotenv.2013.01.032.

(6) Tsibouklis, J.; Stone, M.; Thorpe, A. A.; Graham, P.; Peters, V.; Heerlien, R.; Smith, J. R.; Green, K. L.; Nevell, T. G. Preventing bacterial adhesion onto surfaces: the low-surface-energy approach. Biomaterials 1999, 20 (13), 1229-1235.

(7) Weber, D. J.; Rutala, W. A. Self-disinfecting surfaces: review of current methodologies and future prospects. American journal of infection control 2013, 41 (5 Suppl), S31-5, DOI: 10.1016/j.ajic.2012.12.005.

(8) Bakhsheshi-Rad, H. R.; Hamzah, E.; Ismail, A. F.; Aziz, M.; Daroonparvar, M.; Saebnoori, E.; Chami, A. In vitro degradation behavior, antibacterial activity and cytotoxicity of $\mathrm{TiO}_{2}$ MAO/ZnHA composite coating on $\mathrm{Mg}$ alloy for orthopedic implants. Surface and Coatings Technology 2018, 334, 450-460, DOI: https://doi.org/10.1016/j.surfcoat.2017.11.027. 
(9) Rtimi, S.; Dionysiou, D. D.; Pillai, S. C.; Kiwi, J. Advances in catalytic/photocatalytic bacterial inactivation by nano $\mathrm{Ag}$ and $\mathrm{Cu}$ coated surfaces and medical devices. Applied Catalysis B: Environmental 2019, 240, 291-318, DOI: 10.1016/j.apcatb.2018.07.025.

(10) Rutala, W. A.; Weber, D. J. New disinfection and sterilization methods. Emerging infectious diseases 2001, 7 (2), 348.

(11) Bonetta, S.; Bonetta, S.; Motta, F.; Strini, A.; Carraro, E. Photocatalytic bacterial inactivation by $\mathrm{TiO}_{2}$ coated surface. $A M B$ Express 2013, 3, 59 .

(12) Mills, A.; Le Hunte, S. An overview of semiconductor photocatalysis. Journal of photochemistry and photobiology A: Chemistry 1997, 108 (1), 1-35.

(13) Jacoby, W. A.; Maness, P. C.; Wolfrum, E. J.; Blake, D. M.; Fennell, J. A. Mineralization of bacterial cell mass on a photocatalytic surface in air. Environmental Science \& Technology 1998, 32 (17), 2650-2653.

(14) Benabbou, A.; Derriche, Z.; Felix, C.; Lejeune, P.; Guillard, C. Photocatalytic inactivation of Escherischia coli: Effect of concentration of $\mathrm{TiO}_{2}$ and microorganism, nature, and intensity of UV irradiation. Applied Catalysis B: Environmental 2007, 76 (3), 257-263.

(15) Kühn, K. P.; Chaberny, I. F.; Massholder, K.; Stickler, M.; Benz, V. W.; Sonntag, H.-G.; Erdinger, L. Disinfection of surfaces by photocatalytic oxidation with titanium dioxide and UVA light. Chemosphere 2003, 53 (1), 71-77, DOI: 10.1016/s0045-6535(03)00362-x. 
(16) Adamek, E.; Baran, W.; Ziemiańska-Błaszczyk, J.; Sobczak, A. Immobilisation of TiO $2-\mathrm{P} 25$ on a glass fibre mat: Preparation, photocatalytic activity and stability. Solar Energy 2019, 188, 1232-1242, DOI: 10.1016/j.solener.2019.07.034.

(17) Barthomeuf, M.; Castel, X.; Le Gendre, L.; Louis, J.; Denis, M.; Pissavin, C. Effect of titanium dioxide film thickness on photocatalytic and bactericidal activities against Listeria monocytogenes. Photochem Photobiol 2019, 95 (4), 1035-1044, DOI: 10.1111/php.13078.

(18) Ganguly, P.; Byrne, C.; Breen, A.; Pillai, S. C. Antimicrobial activity of photocatalysts: Fundamentals, mechanisms, kinetics and recent advances. Applied Catalysis B: Environmental 2018, 225, 51-75, DOI: 10.1016/j.apcatb.2017.11.018.

(19) Clemente, A.; Ramsden, J. J.; Wright, A.; Iza, F.; Morrissey, J. A.; Li Puma, G.; Malik, D. J. Staphylococcus aureus resists UVA at low irradiance but succumbs in the presence of $\mathrm{TiO}_{2}$ photocatalytic coatings. Journal of photochemistry and photobiology. B, Biology 2019, 193, 131139, DOI: 10.1016/j.jphotobiol.2019.02.009.

(20) Ohtani, B.; Prieto-Mahaney, O. O.; Li, D.; Abe, R. What is Degussa (Evonik) P25? Crystalline composition analysis, reconstruction from isolated pure particles and photocatalytic activity test. Journal of Photochemistry and Photobiology A: Chemistry 2010, 216 (2-3), 179-182, DOI: 10.1016/j.jphotochem.2010.07.024. 
(21) van Grieken, R.; Marugán, J.; Sordo, C.; Martínez, P.; Pablos, C. Photocatalytic inactivation of bacteria in water using suspended and immobilized silver- $\mathrm{TiO}_{2}$. Applied Catalysis B: Environmental 2009, 93 (1-2), 112-118, DOI: 10.1016/j.apcatb.2009.09.019.

(22) Karunakaran, C.; Abiramasundari, G.; Gomathisankar, P.; Manikandan, G.; Anandi, V. Preparation and characterization of $\mathrm{ZnO}-\mathrm{TiO}_{2}$ nanocomposite for photocatalytic disinfection of bacteria and detoxification of cyanide under visible light. Materials Research Bulletin 2011, 46 (10), 1586-1592, DOI: https://doi.org/10.1016/j.materresbull.2011.06.019.

(23) Zahid, M.; Papadopoulou, E. L.; Suarato, G.; Binas, V. D.; Kiriakidis, G.; Gounaki, I.; Moira, O.; Venieri, D.; Bayer, I. S.; Athanassiou, A. Fabrication of visible light-induced antibacterial and self-cleaning cotton fabrics using manganese doped $\mathrm{TiO}_{2}$ nanoparticles. ACS Applied Bio Materials 2018, 1 (4), 1154-1164, DOI: 10.1021/acsabm.8b00357.

(24) Ploux, L.; Anselme, K.; Dirani, A.; Ponche, A.; Soppera, O.; Roucoules, V. Opposite responses of cells and bacteria to micro/nanopatterned surfaces prepared by pulsed plasma polymerization and UV-irradiation. Langmuir : the ACS journal of surfaces and colloids 2009, 25 (14), 8161-9, DOI: 10.1021/la900457f.

(25) Yao, N.; Lun Yeung, K. Investigation of the performance of $\mathrm{TiO}_{2}$ photocatalytic coatings. Chem. Eng. J. 2011, 167 (1), 13-21, DOI: 10.1016/j.cej.2010.11.061.

(26) Zhang, S.; Liang, X.; Gadd, G. M.; Zhao, Q. Advanced titanium dioxidepolytetrafluorethylene $\left(\mathrm{TiO}_{2}-\mathrm{PTFE}\right)$ nanocomposite coatings on stainless steel surfaces with 
antibacterial and anti-corrosion properties. Applied Surface Science 2019, 490, 231-241, DOI: 10.1016/j.apsusc.2019.06.070.

(27) Rincon, A. Effect of $\mathrm{pH}$, inorganic ions, organic matter and $\mathrm{H}_{2} \mathrm{O}_{2}$ on E. coli $\mathrm{K} 12$ photocatalytic inactivation by $\mathrm{TiO}_{2}$ Implications in solar water disinfection. Applied Catalysis B: Environmental 2004, 51 (4), 283-302, DOI: 10.1016/j.apcatb.2004.03.007.

(28) Kubacka, A.; Diez, M. S.; Rojo, D.; Bargiela, R.; Ciordia, S.; Zapico, I.; Albar, J. P.; Barbas, C.; Martins dos Santos, V. A.; Fernandez-Garcia, M.; Ferrer, M. Understanding the antimicrobial mechanism of $\mathrm{TiO}_{2}$-based nanocomposite films in a pathogenic bacterium. Scientific reports 2014, 4, 4134, DOI: $10.1038 /$ srep04134.

(29) De Dicatillo, C. L.; Correa, M. G.; Martínez, F. B.; Streitt, C.; Galotto, M. J. Antimicrobial effect of titanium dioxide nanoparticles [Online]; IntechOpen 2020, DOI: 10.5772/intechopen.90891. https://www.intechopen.com/online-first/antimicrobial-effect-oftitanium-dioxide-nanoparticles (accessed July 31, 2020).

(30) Bruno-Bárcena, J. M.; Azcárate-Peril, M. A.; Hassan, H. M. Role of antioxidant enzymes in bacterial resistance to organic acids. Applied and environmental microbiology 2010, 76 (9), 2747 2753.

(31) Alhasawi, A.; Castonguay, Z.; Appanna, N. D.; Auger, C.; Appanna, V. D. Glycine metabolism and anti-oxidative defence mechanisms in Pseudomonas fluorescens. Microbiological research 2015, 171, 26-31, DOI: 10.1016/j.micres.2014.12.001. 
(32) Koizumi, Y.; Yamada, R.; Nishioka, M.; Matsumura, Y.; Tsuchido, T.; Taya, M. Deactivation kinetics of Escherichia coli cells correlated with intracellular superoxide dismutase activity in photoreaction with titanium dioxide particles. Journal of Chemical Technology and Biotechnology 2002, $77(6), 671-677$.

(33) Gogniat, G.; Dukan, $\mathrm{S} . \mathrm{TiO}_{2}$ photocatalysis causes DNA damage via Fenton reactiongenerated hydroxyl radicals during the recovery period. Applied and environmental microbiology 2007, 73 (23), 7740-7743.

(34) Rincón, A.; Pulgarin, C. Photocatalytical inactivation of E. coli: effect of (continuousintermittent) light intensity and of (suspended-fixed) $\mathrm{TiO}_{2}$ concentration. Applied Catalysis B: Environmental 2003, 44 (3), 263-284.

(35) Yan, Y.; Keller, V.; Keller, N. On the role of $\mathrm{BmimPF}_{6}$ and P/F- containing additives in the sol-gel synthesis of $\mathrm{TiO}_{2}$ photocatalysts with enhanced activity in the gas phase degradation of methyl ethyl ketone. Applied Catalysis B: Environmental 2018, 234, 56-69, DOI: 10.1016/j.apcatb.2018.04.027.

(36) Jung, M. H.; Chu, M. J.; Kang, M. G. TiO 2 nanotube fabrication with highly exposed (001) facets for enhanced conversion efficiency of solar cells. Chemical communications 2012, 48 (41), 5016-5018, DOI: 10.1039/c2cc31047c.

(37) Doniach, S.; Sunjic, M. Many-electron singularity in X-ray photoemission and X-ray line spectra from metals. Journal of Physics C: Solid State Physics 1970, 3 (2), 285. 
(38) Shirley, D. A. High-resolution x-ray photoemission spectrum of the valence bands of gold. Physical Review B 1972, 5 (12), 4709-4714.

(39) Miao, H.; Ratnasingam, S.; San Pu, C.; Desai, M. M.; Sze, C. C. Dual fluorescence system for flow cytometric analysis of Escherichia coli transcriptional response in multi-species context. Journal of microbiological methods 2009, 76 (2), 109-119.

(40) Vidal, O.; Longin, R.; Prigent-Combaret, C.; Dorel, C.; Hooreman, M.; Lejeune, P. Isolation of an Escherichia coli K-12 mutant strain able to form biofilms on inert surfaces: involvement of a new ompR allele that increases curli expression. Journal of bacteriology 1998, 180 (9), 24422449.

(41) Junker, L. M.; Toba, F. A.; Hay, A. G. Transcription in Escherichia coli PHL628 biofilms. FEMS microbiology letters 2007, 268 (2), 237-43, DOI: 10.1111/j.1574-6968.2006.00585.x.

(42) Schaule, G.; Flemming, H.; Ridgway, H. Use of 5-cyano-2, 3-ditolyl tetrazolium chloride for quantifying planktonic and sessile respiring bacteria in drinking water. Applied and Environmental Microbiology 1993, 59 (11), 3850-3857.

(43) LeChevallier, M. W.; Seidler, R. J.; Evans, T. Enumeration and characterization of standard plate count bacteria in chlorinated and raw water supplies. Applied and Environmental Microbiology 1980, 40 (5), 922-930.

(44) Scherrer, B. Biostatistique, vol. 1. Gaëtan Morin éditeur (816 pp.) 2007. 
(45) Li, B.; Logan, B. E. Bacterial adhesion to glass and metal-oxide surfaces. Colloids and surfaces. B, Biointerfaces 2004, 36 (2), 81-90, DOI: 10.1016/j.colsurfb.2004.05.006.

(46) Suttiponparnit, K.; Jiang, J.; Sahu, M.; Suvachittanont, S.; Charinpanitkul, T.; Biswas, P. Role of surface area, primary particle size, and crystal phase on titanium dioxide nanoparticle dispersion properties. Nanoscale Res Lett 2011, 6 (1), 27.

(47) Maira, A. J.; Yeung, K. L.; Lee, C. Y.; Yue, P. L.; Chan, C. K. Size effects in gas-phase photooxidation of trichloroethylene using nanometer-sized $\mathrm{TiO}_{2}$ catalysts. Journal of Catalysis $\mathbf{2 0 0 0}$, 192 (1), 185-196, DOI: 10.1006/jcat.2000.2838.

(48) Anselme, K.; Davidson, P.; Popa, A. M.; Giazzon, M.; Liley, M.; Ploux, L. The interaction of cells and bacteria with surfaces structured at the nanometre scale. Acta biomaterialia 2010, 6 (10), 3824-46, DOI: 10.1016/j.actbio.2010.04.001.

(49) Tong, T.; Shereef, A.; Wu, J.; Binh, C. T.; Kelly, J. J.; Gaillard, J. F.; Gray, K. A. Effects of material morphology on the phototoxicity of nano- $\mathrm{TiO}_{2}$ to bacteria. Environ Sci Technol 2013, 47 (21), 12486-95, DOI: 10.1021/es403079h.

(50) Pryor, W. A. Oxy-radicals and related species: their formation, lifetimes, and reactions. Annual Review of Physiology 1986, 48 (1), 657-667. 
(51) Takeuchi, H.; Gomi, T.; Shishido, M.; Watanabe, H.; Suenobu, N. Neutrophil elastase contributes to extracellular matrix damage induced by chronic low-dose UV irradiation in a hairless mouse photoaging model. Journal of dermatological science 2010, 60 (3), 151-158.

(52) D’Haeze, W.; Glushka, J.; De Rycke, R.; Holsters, M.; Carlson, R. W. Structural characterization of extracellular polysaccharides of Azorhizobium caulinodans and importance for nodule initiation on Sesbania rostrata. Molecular microbiology 2004, 52 (2), 485-500.

(53) Costerton, J. W. Introduction to biofilm. International Journal of Antimicrobial Agents 1999, 11 (3-4), 217-221, DOI: 10.1016/s0924-8579(99)00018-7.

(54) Vollmer, W.; Blanot, D.; de Pedro, M. A. Peptidoglycan structure and architecture. FEMS microbiology reviews 2008, 32 (2), 149-67, DOI: 10.1111/j.1574-6976.2007.00094.x.

(55) Sunada, K.; Watanabe, T.; Hashimoto, K. Studies on photokilling of bacteria on $\mathrm{TiO}_{2}$ thin film. Journal of Photochemistry and Photobiology A: Chemistry 2003, 156 (1), 227-233.

(56) Maness, P. C.; Smolinski, S.; Blake, D. M.; Huang, Z.; Wolfrum, E. J.; Jacoby, M. A. Bactericidal activity of photocatalytic $\mathrm{TiO}_{2}$ reaction toward an understanding of its killing mechanism. Applied and Environmental Microbiology 1999, 65 (9), 4094-4098.

(57) Kiwi, J.; Nadtochenko, V. Evidence for the mechanism of photocatalytic degradation of the bacterial wall membrane at the $\mathrm{TiO}_{2}$ interface by ATR-FTIR and laser kinetic spectroscopy. Langmuir : the ACS journal of surfaces and colloids 2005, 21 (10), 4631-4641. 
(58) Pal, A.; Pehkonen, S. O.; Yu, L. E.; Ray, M. B. Photocatalytic inactivation of Gram-positive and Gram-negative bacteria using fluorescent light. Journal of Photochemistry and Photobiology A: Chemistry 2007, 186 (2-3), 335-341, DOI: 10.1016/j.jphotochem.2006.09.002.

(59) Kashket, E. R. Bioenergetics of lactic acid bacteria: cytoplasmic pH and osmotolerance. FEMS microbiology reviews 1987, 3 (3), 233-244.

(60) Ofek, I.; Beachey, E. H.; Jefferson, W.; Campbell, G. L. Cell membrane-binding properties of group-A Streptococcal lipoteichoic acid. Journal of Experimental Medicine 1975, 141 (5), 9901003, DOI: 10.1084/jem.141.5.990.

(61) Zeller, T.; Klug, G. Detoxification of hydrogen peroxide and expression of catalase genes in Rhodobacter. Microbiology 2004, 150 (10), 3451-3462.

(62) Groves, M. R.; De Orue Lucana, D. O. Adaptation to oxidative stress by Gram-positive bacteria: the redox sensing system HbpS-SenS-SenR from Streptomyces reticuli. Appl Microbiol Microb Biotechnol 2010.

(63) Hassan, H. M.; Fridovich, I. Enzymatic defenses against the toxicity of oxygen and of streptonigrin in Escherichia coli. Journal of Bacteriology 1977, 129 (3), 1574-1583.

(64) Jacobs, N.; Conti, S. Effect of hemin on the formation of the cytochrome system of anaerobically grown Staphylococcus epidermidis. Journal of bacteriology 1965, 89 (3), 675-679. 
(65) Qiu, J.; Li, S.; Gray, E.; Liu, H.; Gu, Q.-F.; Sun, C.; Lai, C.; Zhao, H.; Zhang, S. Hydrogenation synthesis of blue $\mathrm{TiO}_{2}$ for high-performance lithium-ion batteries. The Journal of Physical Chemistry C 2014, 118 (17), 8824-8830.

(66) Di Valentin, C.; Pacchioni, G.; Selloni, A. Reduced and n-type doped $\mathrm{TiO}_{2}$ : nature of $\mathrm{Ti}^{3+}$ species. The Journal of Physical Chemistry C 2009, 113 (48), 20543-20552.

(67) Linsebigler, A. L.; Lu, G. Q.; Yates, J. T. Photocatalysis on $\mathrm{TiO}_{2}$ surfaces: principles, mechanisms, and selected results. Chemical reviews 1995, 95 (3), 735-758, DOI: 10.1021/cr00035a013.

(68) Singh, B.; Sharma, N. Mechanistic implications of plastic degradation. Polymer Degradation and Stability 2008, 93 (3), 561-584.

(69) Wang, N.; Feng, J.; Chen, J.; Wang, J.; Yan, W. Adsorption mechanism of phosphate by polyaniline $/ \mathrm{TiO}_{2}$ composite from wastewater. Chem. Eng. J. 2017, 316, 33-40, DOI: 10.1016/j.cej.2017.01.066.

(70) Veuillet, M.; Ploux, L.; Roucoules, V.; Courbeyre, Y.; Gaudichet-Maurin, E. Bacterial adhesion driven by mechanical properties of DMAEMA plasma polymer coatings. 22nd International Symposium on Plasma Chemistry; July 5-10, 2015; Antwerp, Belgium 2015. 
The following graphic will be used for the TOC:

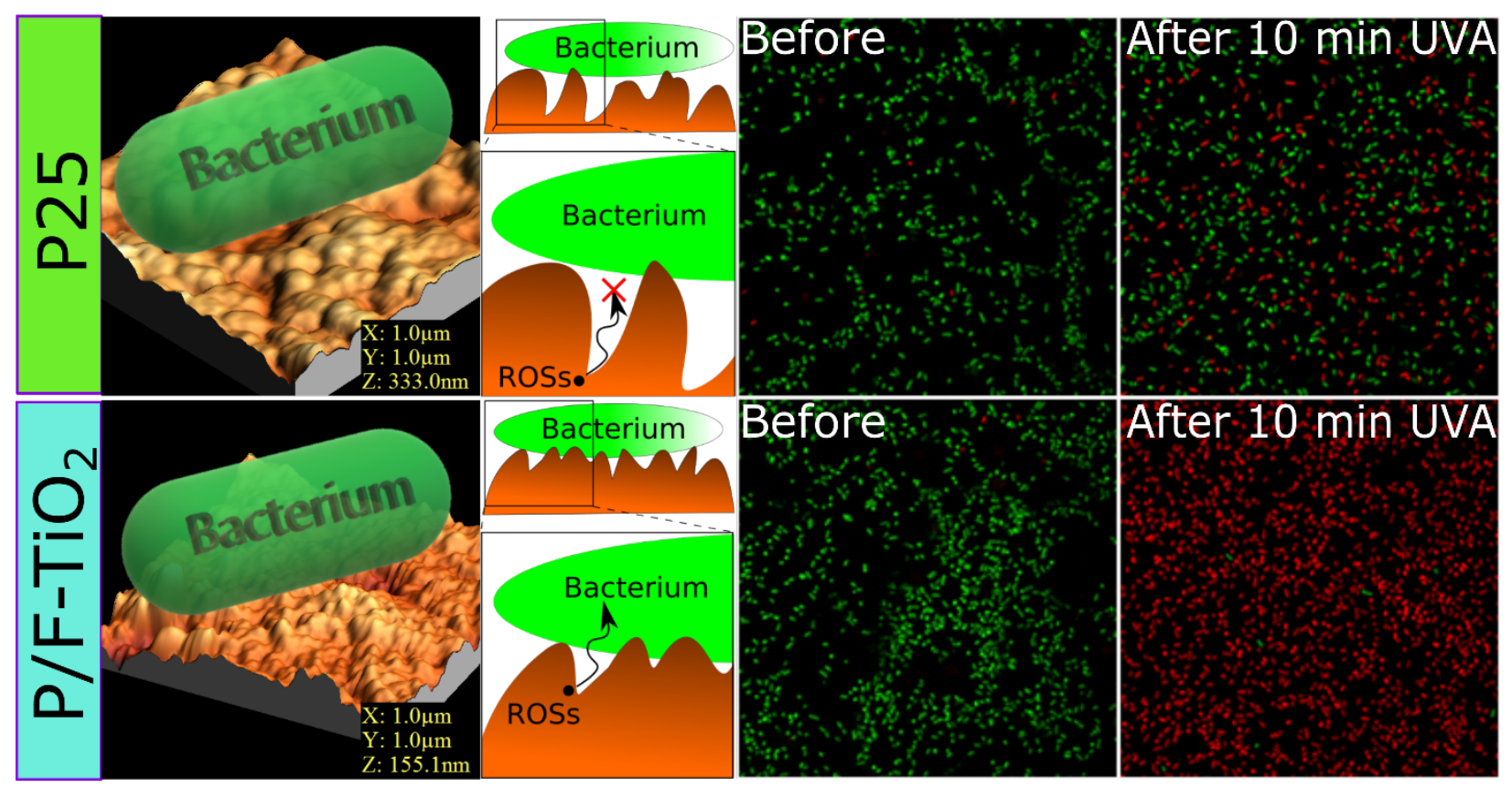

